\title{
Effect of Cooling Rate on Microstructure and Mechanical Properties of Sand-Casted Al-5.0Mg-0.6Mn-0.25Ce Alloy
}

\author{
Hua-Ping Tang ${ }^{1} \cdot$ Qu-Dong Wang ${ }^{1} \cdot$ Chuan Lei $^{1} \cdot$ Kui Wang $^{1} \cdot$ Bing Ye $^{1} \cdot$ Hai-Yan Jiang ${ }^{1} \cdot$ Wen-Jiang Ding ${ }^{1,2}$
}

Received: 1 March 2019 / Revised: 18 April 2019 / Published online: 17 June 2019

(C) The Chinese Society for Metals (CSM) and Springer-Verlag GmbH Germany, part of Springer Nature 2019

\begin{abstract}
This study examines the relationship among cooling rate, microstructure and mechanical properties of a sand-casted $\mathrm{Al}-$ $5.0 \mathrm{Mg}-0.6 \mathrm{Mn}-0.25 \mathrm{Ce}$ (wt \%) alloy subjected to $\mathrm{T} 4$ heat treatment $\left(430^{\circ} \mathrm{C} \times 12 \mathrm{~h}+\right.$ natural aging for 5 days), and the tested alloys with wall thickness varying from 5 to $50 \mathrm{~mm}$ were prepared. The results show that as the cooling rate increases from 0.22 to $7.65 \mathrm{~K} / \mathrm{s}$, the average secondary dendritic arm spacing (SDAS, $\lambda_{2}$ ) decreases from 94.8 to $27.3 \mu \mathrm{m}$. The relation between SDAS and cooling rate can be expressed by an equation: $\lambda_{2}=53.0 R_{\mathrm{c}}^{-0.345}$. Additionally, an increase in cooling rate was shown not only to reduce the amount of the secondary phases, but also to promote the transition from $\mathrm{Al}_{10} \mathrm{Mn}_{2} \mathrm{Ce}$ to $\alpha-\mathrm{Al}_{24}(\mathrm{Mn}, \mathrm{Fe})_{6} \mathrm{Si}_{2}$ phase. Tensile tests show that as the cooling rate increases from 0.22 to $7.65 \mathrm{~K} / \mathrm{s}$, the ultimate tensile strength (UTS) increases from 146.3 to $241.0 \mathrm{MPa}$ and the elongation (EL) increases sharply from 4.4 to $12.2 \%$ for the ascast alloys. Relations of UTS and EL with SDAS were determined, and both the UTS and EL increase linearly with $\left(1 / \lambda_{2}\right)^{0.5}$ and that these changes can be explained by strengthening mechanisms. Most eutectic $\mathrm{Al}_{3} \mathrm{Mg}_{2}$ phases were dissolved during T4 treatment, which in turn further improve the YS, UTS and EL. However, the increment percent of YS, UTS and EL is affected by the cooling rate.
\end{abstract}

Keywords $\mathrm{Al}-\mathrm{Mg}-\mathrm{Mn}$ cast alloys $\cdot$ Cooling rate $\cdot$ Microstructure $\cdot \mathrm{Al}_{10} \mathrm{Mn}_{2} \mathrm{Ce} \cdot$ Mechanical properties

\section{Introduction}

$\mathrm{Al}-\mathrm{Mg}$ alloys have a reputation for providing good ductility, excellent corrosion resistance and high specific stiffness, and thus they have been found to be applied in a variety of industries ranging from consumer packaging to automation and shipbuilding $[1,2]$. As the $\mathrm{Al}-\mathrm{Mg}$ alloys undergo solidification, several impurities containing $\mathrm{Fe}$ are introduced to form at inter-dendritic regions and compromise the ductility of the overall alloy. Several secondary phases such as eutectic $\mathrm{Al}_{3} \mathrm{Mg}_{2}$ and the needlelike $\mathrm{Al}_{3} \mathrm{Fe}$ appear within the microstructure due to segregation of alloying elements [3].

Available online at http://link.springer.com/journal/40195

Qu-Dong Wang

wangqudong@sjtu.edu.cn

1 National Engineering Research Center of Light Alloy Net Forming, Shanghai Jiao Tong University, Shanghai 200240, China

2 State Key Laboratory of Metal Matrix Composites, Shanghai Jiao Tong University, Shanghai 200240, China
The presence of these secondary phases can degrade the mechanical properties severely and even cause the brittleness of the alloys [4]. To relieve the harmful effect of these impurities on the mechanical properties of $\mathrm{Al}-\mathrm{Mg}$ alloys, a T4 heat treatment (involving solution treatment) and natural aging process are commonly utilized to dissolve the eutectic $\mathrm{Al}_{3} \mathrm{Mg}_{2}$ phase $[5,6] . \mathrm{Mn}$ is then added to the alloys to modify the morphology of Fe-rich intermetallic compounds [7]. Recent research has also reported that the addition of $\mathrm{Ce}$ to $\mathrm{Al}$ alloys can refine $\mathrm{Fe}$-rich intermetallic compounds, leading to an improvement in strength [8].

The mechanical properties of $\mathrm{Al}-\mathrm{Mg}$ alloys are mainly dependent on their internal microstructure, and thus the factor relating to thermal parameters and alloy compositions is the major effect on these properties. The cooling rate is one of the important thermal parameters and can greatly affect the microstructure of the alloy. Increasing cooling rate not only reduces the primary and secondary dendrite arm spacings of $\alpha$-Al phase, but also affects the $\mathrm{Al}_{3} \mathrm{Mg}_{2}$ eutectic phase and $\mathrm{Fe}-/ \mathrm{Mn}$-rich intermetallic phase during solidification [9]. Specifically, a high cooling rate may inhibit the formation of the $\mathrm{Al}_{3} \mathrm{Mg}_{2}$ eutectic phase and 
also refine Fe-/Mn-rich phases. Therefore, it is expected that Al-Mg alloys treated at higher cooling rates will have higher strength obtaining a higher tolerance of $\mathrm{Fe}$ and $\mathrm{Si}$ contents in Al-Mg alloys. Zhang et al. [10] studied the effect of extreme rapid cooling rates on the microstructure and properties of die-casted $\mathrm{Al}-\mathrm{Mg}-\mathrm{Mn}$ alloy, and the results showed that an extremely rapid cooling rate is beneficial to improve mechanical properties. Liu et al. also reported that a higher cooling rate can inhibit the formation of Fe- and Mnrich phases [11] and thus improve the mechanical properties of $\mathrm{Al}-\mathrm{Mg}-\mathrm{Mn}$ alloy manufactured using continuous strip casting methods [12].

Varying the $\mathrm{Mg}$ content will change the effect of the cooling rate on the microstructure, thereby also changing the macroscopic properties of the alloys. Increasing $\mathrm{Mg}$ content increases the difference between liquidus and solidus temperatures [13]. Therefore, if the cooling rate is kept constant while $\mathrm{Mg}$ content is high, the solid solution limit of $\mathrm{Mg}$ in the final solidified area will be reached more quickly and more $\mathrm{Al}_{3} \mathrm{Mg}_{2}$ phase will be present at boundary areas. The increased presence of $\mathrm{Al}_{3} \mathrm{Mg}_{2}$ phases will lead the material to become more brittle decreasing the strength and ductility of the alloys. Gomes et al. [14], however, revealed a different trend: The ultimate tensile strength increases slightly, while the elongation decreases gradually with the increase in the cooling rate for $\mathrm{Al}-1.2 \mathrm{Mg}-1.5 \mathrm{Fe}$ cast alloys. In his study, as $\mathrm{Mg}$ content ranged from 1.2 to $7.0 \%$ at low cooling rates, the ultimate tensile strength is nearly constant, while the elongation increased significantly. As it is known, the relationship between the microstructure and properties $\mathrm{Al}-\mathrm{Mg}$ alloys is quite complex and can be affected greatly both by cooling rate and alloying composition.

Combining with these results in Refs. [10, 11, 14], it can also be reasoned that the mechanical properties of $\mathrm{Al}-\mathrm{Mg}$ alloys with moderate-to-high $\mathrm{Mg}$ content may be more susceptible to cooling rate than that of $\mathrm{Al}-\mathrm{Mg}$ alloys with low $\mathrm{Mg}$ content. When the cooling rate varies between low and medium, the microstructure and properties may change significantly for $\mathrm{Al}-\mathrm{Mg}$ alloys with moderate-to-high $\mathrm{Mg}$ content. Though the cooling rate at lower ranges may have a measurable effect on the microstructure and properties of alloys, there are very few studies for examining these relationships. These studies will greatly benefit sand casting, which is known to have a relatively low cooling rate, and most $\mathrm{Al}-\mathrm{Mg}$ alloy castings are sand-casted due to their severe cracking tendency in permanent gravity casting [15].

This study aims to investigate the effect of cooling rate (ranging from 0.22 to $7.65 \mathrm{~K} / \mathrm{s}$ ) on the microstructure and mechanical properties of sand-casted $\mathrm{Al}-5.0 \mathrm{Mg}-0.6 \mathrm{Mn}-0.25 \mathrm{Ce}$ alloys (wt \%) under the as-cast and T4-treated conditions. The relationships among cooling rate, microstructure characteristics and the mechanical properties are examined under the as-cast condition, in turn, providing more data for commercial production. Additionally, the effect of cooling rate on the mechanical properties under T4-treated condition is also given attention.

\section{Materials and Methods}

An ingot with a composition of $\mathrm{Al}-5.0 \mathrm{Mg}-0.6 \mathrm{Mn}-0.25 \mathrm{Ce}$ was melted in an iron crucible in an electrical resistance furnace at $730{ }^{\circ} \mathrm{C}$. To prevent impurity iron from melting into Al melt, a mixed coating of sodium silicate and zinc oxide powder was brushed on the iron crucible during the melting process. The melt was degassed with $0.2 \mathrm{wt} \% \mathrm{C}_{2} \mathrm{Cl}_{6}$ before pouring into a tailor-made sand mold coated with graphite powder on the internal surface. The sand mold was made of self-hardening resin sand and preheated at $200{ }^{\circ} \mathrm{C}$ for $10 \mathrm{~min}$ in the drying oven. The design of the filling is shown in Fig. 1a. After pouring the melted $\mathrm{Al}$ into this mold, a step shape casting was obtained. The dimensions of the casting are shown in Fig. 1b.

Cooling curves were measured using a $K$-type thermocouple connected to a data acquisition system for determining the transformation temperature. The thermocouple was inserted into the midsection at the heights of each step, as
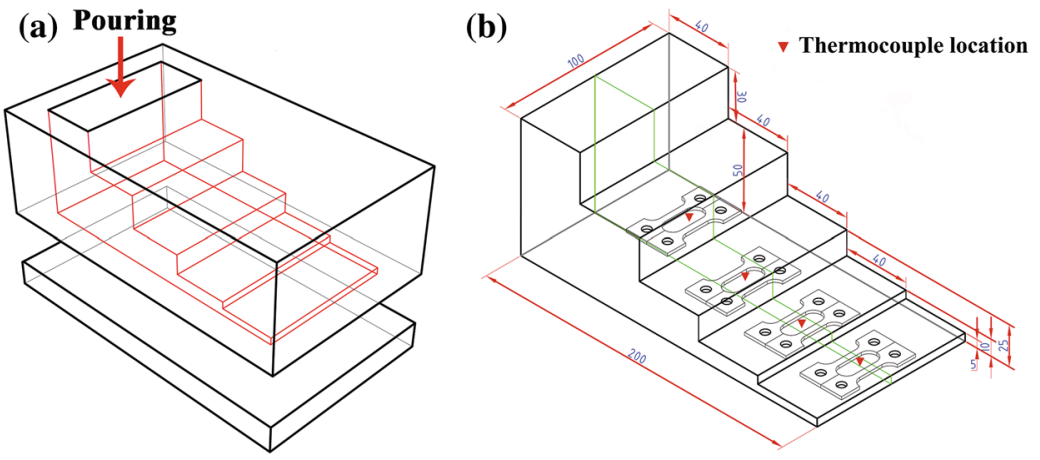

(c)

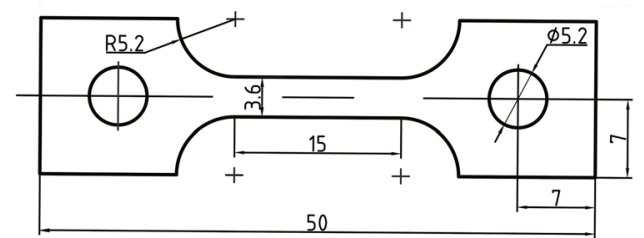

$T=1.8$

Fig. 1 Schematic illustration of step shape sand mold $\mathbf{a}$, casting $\mathbf{b}$, the dimension for tensile specimen $\mathbf{c}$ (unit: $\mathrm{mm}$ ) 
shown in Fig. 1b. The cooling rates $\left(R_{\mathrm{c}}\right)$ were determined by the formula:

$R_{\mathrm{c}}=\left(T_{\mathrm{Liq}}-T_{\mathrm{Sol}}\right) /\left(t_{\mathrm{Sol}}-t_{\mathrm{Liq}}\right)$,

where $T_{\mathrm{Liq}}$ and $T_{\mathrm{Sol}}$ are the liquidus and solidus temperatures $\left({ }^{\circ} \mathrm{C}\right)$, while $t_{\mathrm{Liq}}$ and $t_{\mathrm{Sol}}$ are the times from the cooling curves corresponding to liquidus and solidus temperatures, respectively. The chemical composition of the alloys after casting was measured by using an inductively coupled plasma optical emission spectrometer and the result of composition is given in Table 1. The as-cast alloys were subjected to T4 heat treatment, which is comprised of a solution treatment at $430{ }^{\circ} \mathrm{C}$ (below $450{ }^{\circ} \mathrm{C}$, the melting point of $\mathrm{Al}_{3} \mathrm{Mg}_{2}$ phase) for $12 \mathrm{~h}$, followed by the quenching of the sample into an ice water bath, and finally performing a natural aging process at room temperature for 5 days, which was used to simulate the practical production times.

Samples for microstructure analysis and tensile tests were taken from the central area of each step as shown in Fig. $1 b$. The dimension of the tensile specimen is shown in Fig. 1c. The samples for microstructure analysis were prepared and etched with Keller's reagent. The phases in the as-cast alloys were identified using a poly-functional X-ray diffractometer (XRD) with a $\mathrm{Cu} K \alpha$ source operating at $25 \mathrm{kV}, 50 \mathrm{~mA}$ and a scanning rate of $5 \% \mathrm{~min}$. Microstructural observation was performed using a Zeiss Axio Observer A1 optical microscope (OM) and a FEI NOVA 230 field-emission scanning electron microscopy (SEM) equipped with an AZtec

Table 1 Chemical composition of the as-cast alloy (wt $\%$ )

\begin{tabular}{llllll}
\hline $\mathrm{Mg}$ & $\mathrm{Mn}$ & $\mathrm{Ce}$ & $\mathrm{Si}$ & $\mathrm{Fe}$ & $\mathrm{Al}$ \\
\hline 4.91 & 0.67 & 0.23 & 0.29 & 0.10 & $\mathrm{Bal}$. \\
\hline
\end{tabular}

X-Max 80 X-ray energy-dispersive spectroscope (EDS). The secondary dendritic arm spacing (SDAS) was measured using the linear intercept method under an examination of 30 micrographs at $100 \times$ magnification. The average area fraction of $\mathrm{Al}_{3} \mathrm{Mg}_{2}$ and Mn-rich phase was measured using Image Pro-Plus 6.0 software by examining 30 SEM micrographs. Furthermore, transmission electron microscopy specimens were cut from the ends of the tensile specimen. The cut wafers were then mechanically thinned to $\sim 100 \mu \mathrm{m}$ in thickness, punched into 3-mm disks, and twin-jet-electropolished in a solution of $4 \mathrm{vol} \%$ perchloric acid and 96 vol\% ethanol cooled to about $-30{ }^{\circ} \mathrm{C}$. TEM observation was accomplished using a JEM-2100 transmission electron microscopy operating at $200 \mathrm{kV}$.

Vickers hardness testing was carried out on polished specimens at a load of $5 \mathrm{~N}$ and a holding time of $10 \mathrm{~s}$. Each result is determined as the average value of six hardness measurements. Moreover, the tensile test was conducted on Zwick/Roell Z020 tensile machine with an initial strain rate of $1.6 \times 10^{-4} \mathrm{~s}^{-1}$ at room temperature. The three tests were conducted for each cooling rate, and the average value was recorded.

\section{Results}

\subsection{Determination of Cooling Rates}

Figure 2a shows the cooling curves of the as-cast Al-5.0Mg-0.6Mn-0.25Ce alloys with different thicknesses. From this figure, a clear observation is that the solidification time varies dramatically with the casting thickness. To determine the transformation temperatures of the new phases during the solidification process, the first derivative of the cooling curve was graphed. The cooling curves for
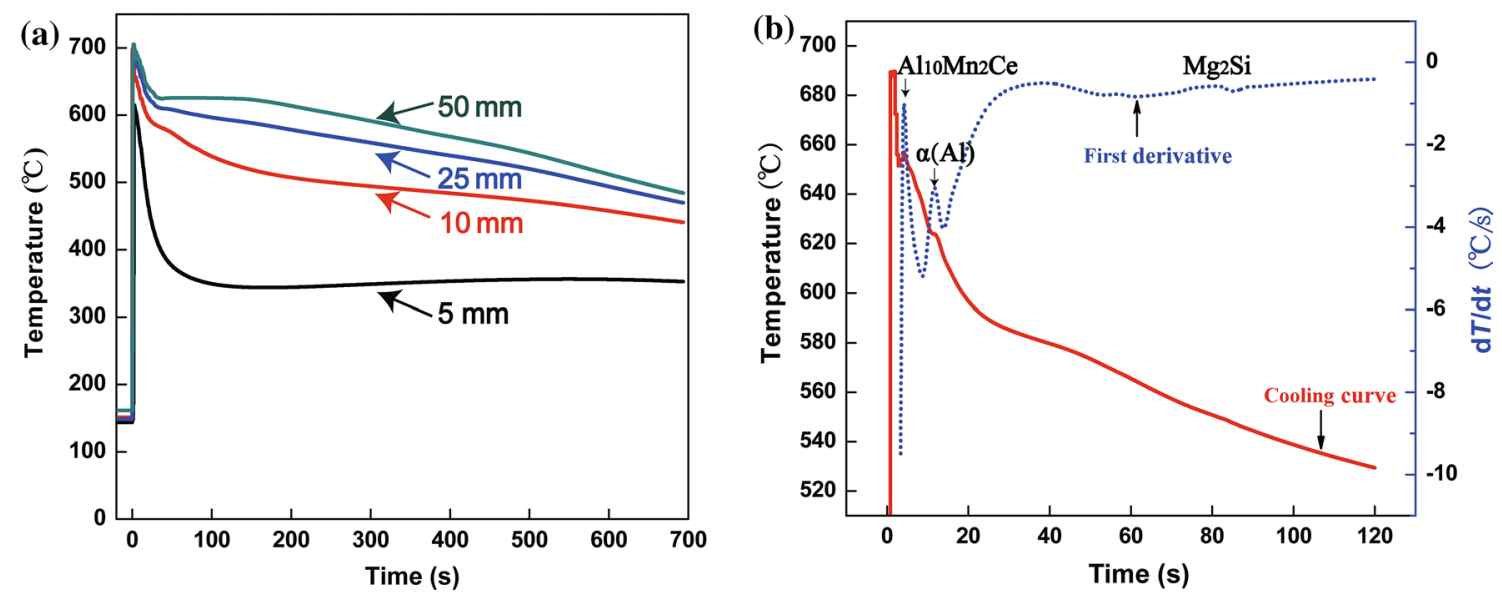

Fig. 2 Cooling curves of the as-cast $\mathrm{Al}-5.0 \mathrm{Mg}-0.6 \mathrm{Mn}-0.25 \mathrm{Ce}$ alloys with different thicknesses a and the cooling curve (red solid line) and the corresponding first derivative (blue dashed line) of the as-cast alloy with a thickness of $10 \mathrm{~mm} \mathbf{b}$ 
the as-cast alloy (with a thickness of $10 \mathrm{~mm}$ ) and the corresponding first derivative are shown in Fig. 2b. As shown in Haq et al. [16], inflection points on the derivative curve correlate the formation of a new phase related to the transformation temperature. When analyzing the first derivative graph (Fig. 2b), three distinct inflection points can be observed correlating to three distinct phase transformations. Comparing the phase seen from the results of the data with the Al-Mn-Ce phase diagram shown in Coury et al. [17] and the $\mathrm{Al}-\mathrm{Mg}-\mathrm{Mn}$ phase diagram given by $\mathrm{Yi}$ et al. [18], it was determined that the inflection points found correspond to the formation of the $\mathrm{Al}_{10} \mathrm{Mn}_{2} \mathrm{Ce}$ phase, $\alpha(\mathrm{Al})$ dendrite phase and $\mathrm{Mg}_{2} \mathrm{Si}$ phase, respectively. It is evident that the formation of $\mathrm{Al}_{10} \mathrm{Mn}_{2} \mathrm{Ce}$ occurs first near the beginning of solidification, while the formation of $\mathrm{Mg}_{2} \mathrm{Si}$ comes last at the end of solidification. Thus, the cooling rates $\left(R_{\mathrm{c}}\right)$ are calculated using the slope of the cooling curve from the temperature range between liquidus and $\mathrm{Mg}_{2} \mathrm{Si}$, and the results are given in Table 2 . The corresponding cooling rates calculated for the thicknesses of 50, 25, 10 and $5 \mathrm{~mm}$ are $0.22,0.33$, 1.39 and $7.65 \mathrm{~K} / \mathrm{s}$, respectively. The range of the cooling rates and thicknesses analyzed in this study (from 0.22 to $7.65 \mathrm{~K} / \mathrm{s}$ ) are consistent with those used in Chen et al. [19] (which analyzed a cooling rate range of $0.19-6.25 \mathrm{~K} / \mathrm{s}$ with the thickness varying from 4 to $30 \mathrm{~mm}$ ).

\subsection{As-Cast Microstructure}

XRD was used to identify phases of the as-cast $\mathrm{Al}-5.0 \mathrm{Mg}-0.6 \mathrm{Mn}-0.25 \mathrm{Ce}$ alloys, and the results are shown in Fig. 3. It is shown that the as-cast alloy mainly consists of $\alpha-\mathrm{Al}_{1} \mathrm{Al}_{3} \mathrm{Mg}_{2}, \mathrm{Al}_{10} \mathrm{Mn}_{2} \mathrm{Ce}$ and $\mathrm{Mg}_{2} \mathrm{Si}$ phases. As increasing cooling rates, the intensities of peaks from the secondary phases appear to decrease. These decreases are likely correlated with the decreases in the amount of secondary phases. Thus, it can be determined that at higher cooling rates, higher amounts of alloying elements are dissolved into the $\alpha$-Al phase, thereby leaving less alloying elements to form the secondary phases.

Figure 4 shows the optical microstructures of the ascast $\mathrm{Al}-5.0 \mathrm{Mg}-0.6 \mathrm{Mn}-0.25 \mathrm{Ce}$ alloys. It is shown that the as-cast microstructure contains $\alpha(\mathrm{Al})$ dendrites, the eutectic $\mathrm{Al}_{3} \mathrm{Mg}_{2}$ phase and other secondary phases. The $\mathrm{Al}_{3} \mathrm{Mg}_{2}$ and other secondary phases are distributed in the

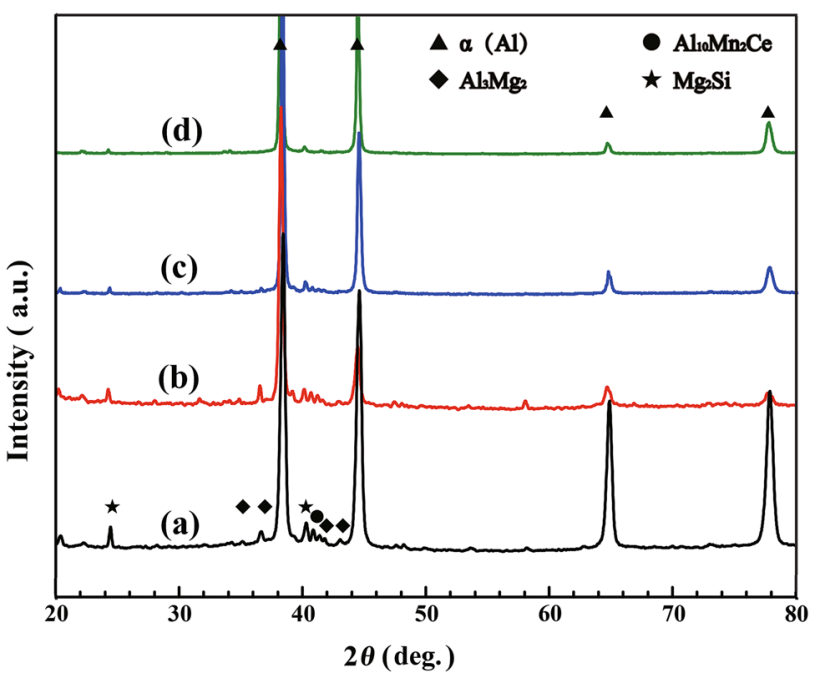

Fig. $3 \mathrm{XRD}$ patterns of the as-cast $\mathrm{Al}-5.0 \mathrm{Mg}-0.6 \mathrm{Mn}-0.25 \mathrm{Ce}$ alloys produced at different cooling rates: a $0.22 \mathrm{~K} / \mathrm{s} ; \mathbf{b} 0.33 \mathrm{~K} / \mathrm{s} ; \mathbf{c} 1.39 \mathrm{~K} / \mathrm{s}$; d $7.65 \mathrm{~K} / \mathrm{s}$

inter-dendritic regions. It is evident that the cooling rate induces a considerable change in the microstructure with reduction in SDAS as shown in Fig. 4a-d. Measured values of SDAS are given in Table 3. A 70\% reduction in SDAS is observed with an increase in the cooling rate from 0.22 to $7.65 \mathrm{~K} / \mathrm{s}$. The regression analysis through the data points of the cooling rate and SDAS shows that the SDAS is a function of the cooling rate (using data from Table 3) and can be represented by the following equation:

$\lambda_{2}=53.0 R_{\mathrm{c}}^{-0.345}$,

where $\lambda_{2}$ represents the SDAS (in $\mu \mathrm{m}$ ) and $R_{\mathrm{c}}$ represents the cooling rate (in $\mathrm{K} / \mathrm{s}$ ). Similar results are also reported in $\mathrm{Al}-11.0 \mathrm{Mg}$ alloys by Liu et al. [20] and Hosseini et al. [21]. These studies reported that increasing the cooling rate could increase the undercooling and the nucleating rates of $\alpha$-Al, thereby reducing the SDAS, which is consistent with the results (Fig. 5) in this study.

Besides the effect on the SDAS, the cooling rate also appears to affect the amount and size of the eutectic $\mathrm{Al}_{3} \mathrm{Mg}_{2}$ phase. As the cooling rate increases from 0.22 to $7.65 \mathrm{~K} / \mathrm{s}$, the average area fraction of the $\mathrm{Al}_{3} \mathrm{Mg}_{2}$ phase decreases from 21.5 to $6.6 \%$, as illustrated in Fig. 4 and
Table 2 Solidification parameters of as-cast alloys with different thicknesses $\left(T_{2}\right.$ : the formation temperature of $\alpha(\mathrm{Al}) ; t_{2}$ : the formation time of $\alpha(\mathrm{Al}) ; T_{3}$ : the formation temperature of $\mathrm{Mg}_{2} \mathrm{Si} ; t_{3}$ : the formation time of $\mathrm{Mg}_{2} \mathrm{Si}$ )

\begin{tabular}{|c|c|c|c|c|c|c|c|c|c|}
\hline \multirow{2}{*}{$\begin{array}{l}\text { Thickness } \\
(\mathrm{mm})\end{array}$} & \multirow[t]{2}{*}{$R_{\mathrm{c}}(\mathrm{K} / \mathrm{s})$} & \multirow[t]{2}{*}{$\Delta T\left({ }^{\circ} \mathrm{C}\right)$} & \multirow[t]{2}{*}{$\Delta t(\mathrm{~s})$} & \multicolumn{2}{|c|}{$\mathrm{Al}_{10} \mathrm{Mn}_{2} \mathrm{Ce}$} & \multicolumn{2}{|l|}{$\alpha(\mathrm{Al})$} & \multicolumn{2}{|l|}{$\mathrm{Mg}_{2} \mathrm{Si}$} \\
\hline & & & & $T_{\text {Liq }}\left({ }^{\circ} \mathrm{C}\right)$ & $t_{\mathrm{Liq}}(\mathrm{s})$ & $\overline{T_{2}\left({ }^{\circ} \mathrm{C}\right)}$ & $t_{2}(\mathrm{~s})$ & $T_{3}\left({ }^{\circ} \mathrm{C}\right)$ & $t_{3}(\mathrm{~s})$ \\
\hline 50 & 0.22 & 69.7 & 419.1 & 654.2 & 15.2 & 626.4 & 31.2 & 556.7 & 450.3 \\
\hline 25 & 0.33 & 69.8 & 292.3 & 656.1 & 11.5 & 626.5 & 20.0 & 556.6 & 312.3 \\
\hline 10 & 1.39 & 79.0 & 71.6 & 657.1 & 4.3 & 629.2 & 9.6 & 550.2 & 81.4 \\
\hline 5 & 7.65 & 63.9 & 8.4 & _- & _- & 614.8 & 2.5 & 550.9 & 10.8 \\
\hline
\end{tabular}



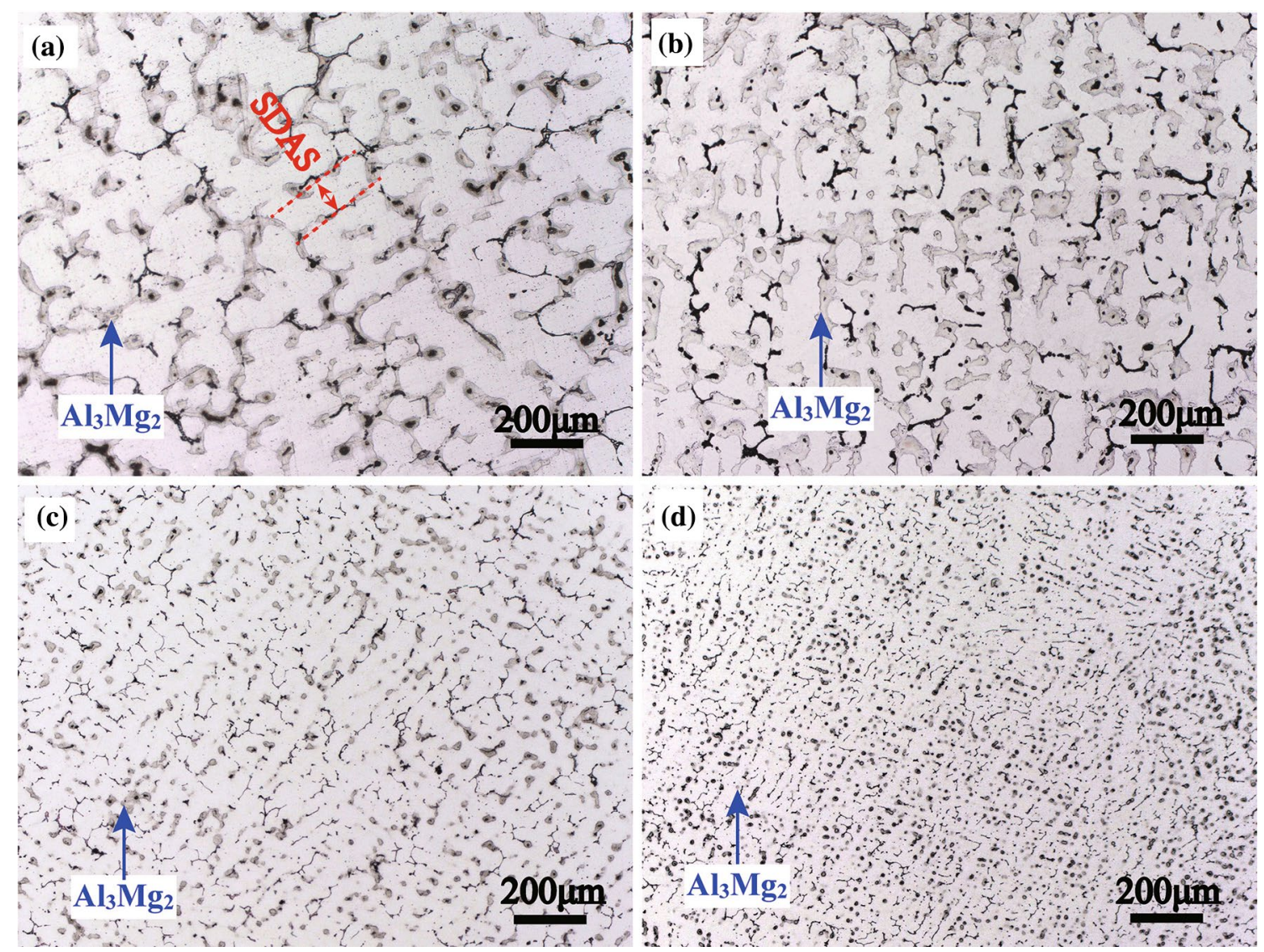

Fig. 4 Optical microstructures of the as-cast $\mathrm{Al}-5.0 \mathrm{Mg}-0.6 \mathrm{Mn}-0.25 \mathrm{Ce}$ alloys under different cooling rates: a $0.22 \mathrm{~K} / \mathrm{s} ; \mathbf{b} 0.33 \mathrm{~K} / \mathrm{s}$; c $1.39 \mathrm{~K} / \mathrm{s}$; d $7.65 \mathrm{~K} / \mathrm{s}$

Table 3 SDAS of $\alpha(\mathrm{Al})$ dendrites, area fraction (\%) of $\mathrm{Al}_{3} \mathrm{Mg}_{2}$ and $\mathrm{Mn}$-rich phases in the as-cast $\mathrm{Al}-5.0 \mathrm{Mg}-0.6 \mathrm{Mn}-0.25 \mathrm{Ce}$ alloys produced at different cooling rates

\begin{tabular}{lllll}
\hline $\begin{array}{l}\text { Thick- } \\
\text { ness } \\
(\mathrm{mm})\end{array}$ & $R_{\mathrm{c}}(\mathrm{K} / \mathrm{s})$ & SDAS $(\mu \mathrm{m})$ & \multicolumn{2}{l}{ Area fraction $(\%)$} \\
\cline { 4 - 5 } \cline { 4 - 5 } & & $\alpha(\mathrm{Al})$ Dendrite & $\mathrm{Al}_{3} \mathrm{Mg}_{2}$ phase & Mn-rich phase \\
\hline 50 & 0.22 & $94.8 \pm 13.2$ & $21.5 \pm 4.6$ & $1.46 \pm 0.15$ \\
25 & 0.33 & $75.7 \pm 12.4$ & $20.8 \pm 3.8$ & $1.40 \pm 0.11$ \\
10 & 1.39 & $44.8 \pm 9.5$ & $8.7 \pm 1.3$ & $0.76 \pm 0.10$ \\
5 & 7.65 & $27.3 \pm 5.5$ & $6.6 \pm 0.9$ & $0.67 \pm 0.08$ \\
\hline
\end{tabular}

Table 3. The reduction in the amount of $\mathrm{Al}_{3} \mathrm{Mg}_{2}$ meets expectations related to the decline in the peak intensity of $\mathrm{Al}_{3} \mathrm{Mg}_{2}$ from XRD results shown in Fig. 3. Furthermore, after comparing the $\mathrm{Al}_{3} \mathrm{Mg}_{2}$ phases in Fig. $4 \mathrm{a}$, b with c, $\mathrm{d}$, it is evident that the size of eutectic $\mathrm{Al}_{3} \mathrm{Mg}_{2}$ phase is reduced from a coarse network structure to a fine granular structure.

Figure 6 shows the SEM micrographs and quantitative EDS results of different points that are given in Table 4. The black phase represents the $\mathrm{Mg}_{2} \mathrm{Si}$ phase with a skeleton-like

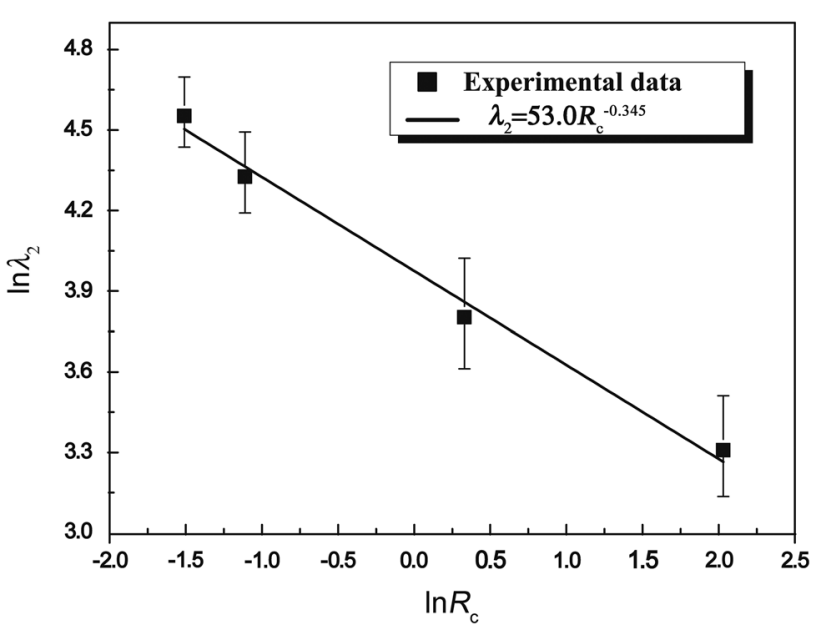

Fig. 5 Relation of SDAS with the cooling rate for the as-cast Al$5.0 \mathrm{Mg}-0.6 \mathrm{Mn}-0.25 \mathrm{Ce}$ alloys

structure. The diagrams show that this phase is significantly reduced with the increase in the cooling rate. The white phases in Fig. 6a-d consist of Al, Mn and Ce elements and 

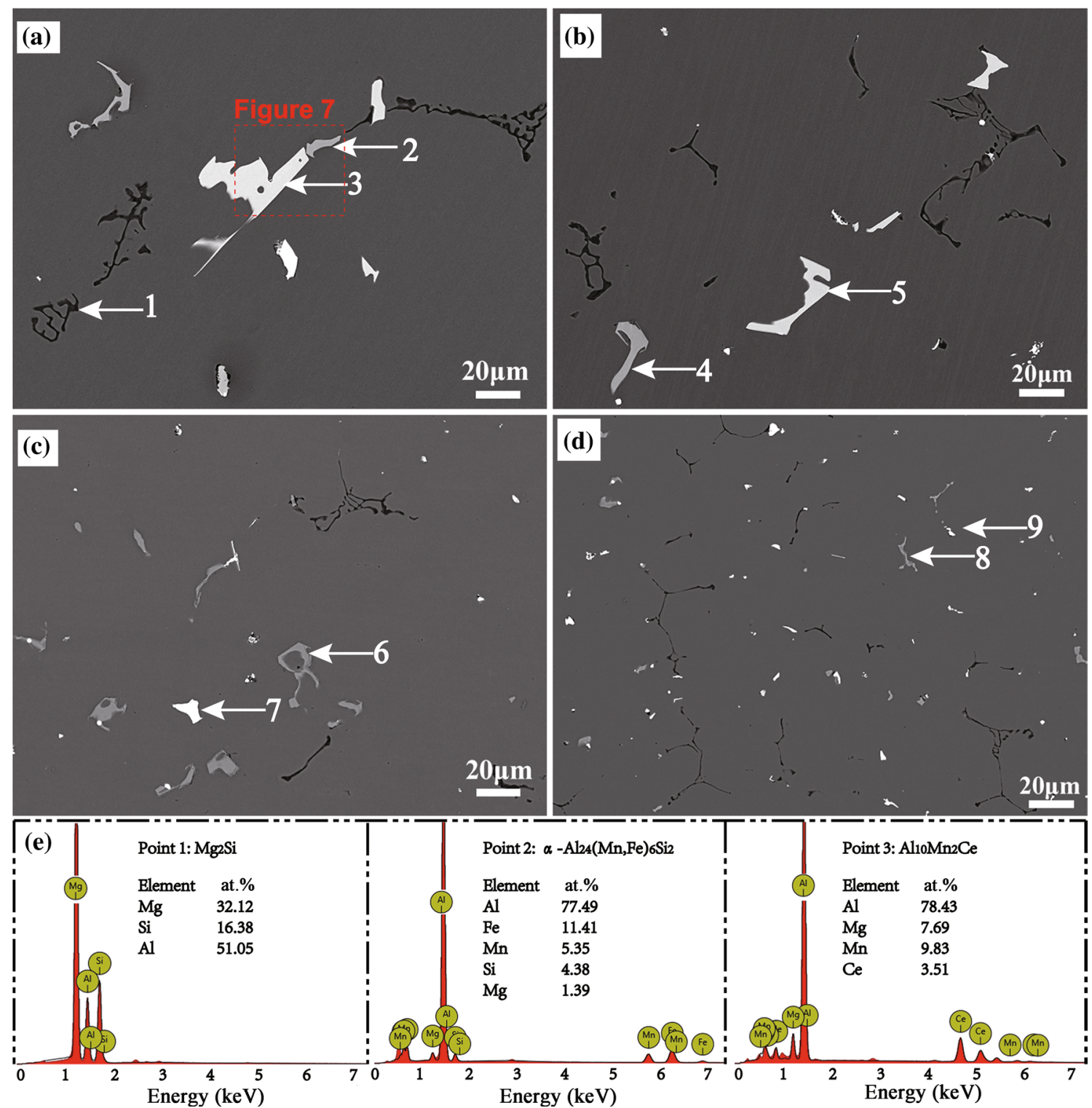

Fig. 6 SEM micrographs showing effect of the cooling rate on the secondary phases in the as-cast $\mathrm{Al}-5.0 \mathrm{Mg}-0.6 \mathrm{Mn}-0.25 \mathrm{Ce}$ alloys: a $0.22 \mathrm{~K} / \mathrm{s}$; b $0.33 \mathrm{~K} / \mathrm{s} ; \mathbf{c} 1.39 \mathrm{~K} / \mathrm{s} ; \mathbf{d} 7.65 \mathrm{~K} / \mathrm{s} ; \mathbf{e}$ corresponding EDS results of points 1,2 and 3

Table 4 EDS results of the secondary phases shown in Fig. 6 (at\%)

\begin{tabular}{lllllcll}
\hline Point & $\mathrm{Al}$ & $\mathrm{Mg}$ & $\mathrm{Mn}$ & $\mathrm{Ce}$ & $\mathrm{Fe}$ & $\mathrm{Si}$ & \multicolumn{1}{c}{ Identified phase } \\
\hline Figure 6a, 1 & 51.05 & 32.12 & 0 & 0 & 0.45 & 16.38 & $\mathrm{Mg}_{2} \mathrm{Si}$ \\
Figure 6a, 2 & 77.49 & 1.39 & 5.35 & 0.04 & 11.41 & 4.38 & $\alpha-\mathrm{Al}_{24}(\mathrm{Mn}, \mathrm{Fe})_{6} \mathrm{Si}_{2}$ \\
Figure 6a, 3 & 78.43 & 7.69 & 9.83 & 3.51 & 0.54 & 0 & $\mathrm{Al}_{10} \mathrm{Mn}_{2} \mathrm{Ce}$ \\
Figure 6b, 4 & 77.94 & 1.74 & 6.31 & 0.02 & 10.35 & 3.63 & $\alpha-\mathrm{Al}_{24}(\mathrm{Mn}, \mathrm{Fe})_{6} \mathrm{Si}_{2}$ \\
Figure 6b, 5 & 80.54 & 7.53 & 8.00 & 3.41 & 0.52 & 0 & $\mathrm{Al}_{10} \mathrm{Mn}{ }_{2} \mathrm{Ce}$ \\
Figure 6c, 6 & 78.38 & 1.65 & 6.15 & 0 & 9.94 & 3.88 & $\alpha-\mathrm{Al}_{24}(\mathrm{Mn}, \mathrm{Fe})_{6} \mathrm{Si}_{2}$ \\
Figure 6c, 7 & 80.99 & 7.53 & 7.75 & 3.21 & 0 & 0 & $\mathrm{Al}_{10} \mathrm{Mn}_{2} \mathrm{Ce}$ \\
Figure 6d, 8 & 77.30 & 3.37 & 7.38 & 0.10 & 8.13 & 3.72 & $\alpha-\mathrm{Al}_{24}(\mathrm{Mn}, \mathrm{Fe})_{6} \mathrm{Si}_{2}$ \\
Figure 6d, 9 & 81.88 & 7.74 & 7.15 & 3.23 & 0 & 0 & $\mathrm{Al}_{10} \mathrm{Mn}_{2} \mathrm{Ce}$ \\
\hline
\end{tabular}


are considered to have a similar composition as $\mathrm{Al}_{10} \mathrm{Mn}_{2} \mathrm{Ce}$. The gray-white phases in Fig. 6a-d consist of $\mathrm{Al}, \mathrm{Mn}, \mathrm{Fe}$, $\mathrm{Si}$ and $\mathrm{Mg}$ elements with a composition analogous to the $\alpha-\mathrm{Al}_{24}(\mathrm{Mn}, \mathrm{Fe})_{6} \mathrm{Si}_{2}$ phase. Because of the similar composition, the gray-white phase can be described as the $\alpha-\mathrm{Al}_{24}(\mathrm{Mn}, \mathrm{Fe})_{6} \mathrm{Si}_{2}$ phase, a Mn-rich phase [22]. Furthermore, as the cooling rate increases from 0.22 to $7.65 \mathrm{~K} / \mathrm{s}$, the average length of the Mn-rich phase decreases from 34.8 to $6.6 \mu \mathrm{m}$ and the average area fraction reduces from 1.46 to $0.76 \%$ (as shown in Table 3). Since the atomic numbers of $\mathrm{Al}$ and $\mathrm{Mg}$ are close, it is difficult to distinguish the eutectic $\mathrm{Al}_{3} \mathrm{Mg}_{2}$ from $\alpha$-Al by SEM observation. Thus, the $\mathrm{Al}_{3} \mathrm{Mg}_{2}$ phases are not observed in Fig. 6. In summary, an increase in the cooling rate reduces the size and amount of the secondary phases for the as-cast alloys.

It is noteworthy that with the increase in the cooling rate, the percentage of $\mathrm{Al}_{10} \mathrm{Mn}_{2} \mathrm{Ce}$ in the Mn-rich phase decreases and that of $\alpha-\mathrm{Al}_{24}(\mathrm{Mn}, \mathrm{Fe})_{6} \mathrm{Si}_{2}$ phase increases (as shown in Fig. 6). This means that an increase in cooling rate promotes the transition from $\mathrm{Al}_{10} \mathrm{Mn}_{2} \mathrm{Ce}$ to the $\mathrm{Al}_{24}(\mathrm{Mn}, \mathrm{Fe})_{6} \mathrm{Si}_{2}$ phase. EDS mapping analysis shown in Fig. 7 indicates that Ce exists primarily in the $\mathrm{Al}_{10} \mathrm{Mn}_{2} \mathrm{Ce}$ phase, rather than in $\alpha-\mathrm{Al}_{24}(\mathrm{Mn}, \mathrm{Fe})_{6} \mathrm{Si}_{2}$ phase, showing that $\mathrm{Ce}$ tends to combine with $\mathrm{Al}$ and $\mathrm{Mn}$ to form $\mathrm{Al}_{10} \mathrm{Mn}_{2} \mathrm{Ce}$ phase. The cooling curve analysis in Fig. $2 \mathrm{~b}$ shows that the formation temperature of the $\mathrm{Al}_{10} \mathrm{Mn}_{2} \mathrm{Ce}$ phase is much higher than that of the $\alpha-\mathrm{Al}_{24}(\mathrm{Mn}, \mathrm{Fe})_{6} \mathrm{Si}_{2}$ phase during solidification. At low cooling rates (such as 0.22 and $0.33 \mathrm{~K} / \mathrm{s}$ ), the $\mathrm{Al}_{10} \mathrm{Mn}_{2} \mathrm{Ce}$ has more time to grow and consume more $\mathrm{Mn}$. As a result, there is less $\mathrm{Mn}$ within the sample to form $\alpha-\mathrm{Al}_{24}(\mathrm{Mn}, \mathrm{Fe})_{6} \mathrm{Si}_{2}$ phase. On the contrary, a higher cooling rate will cause less of the $\mathrm{Al}_{10} \mathrm{Mn}_{2} \mathrm{Ce}$ phase to form and a higher amount of the $\alpha-\mathrm{Al}_{24}(\mathrm{Mn}, \mathrm{Fe})_{6} \mathrm{Si}_{2}$ phase is formed in the overall alloy.

\subsection{T4-treated Microstructure}

Figure 8 shows the optical microstructures of the T4-treated $\mathrm{Al}-5.0 \mathrm{Mg}-0.6 \mathrm{Mn}-0.25 \mathrm{Ce}$ alloys produced at different cooling rates. It is mainly composed of the $\alpha(\mathrm{Al})$ phase, Mn-rich phase and $\mathrm{Mg}_{2} \mathrm{Si}$ phase. When comparing the T4-treated alloy with the as-cast alloys, the eutectic $\mathrm{Al}_{3} \mathrm{Mg}_{2}$ phase is no longer present, while Mn-rich intermetallic and $\mathrm{Mg}_{2} \mathrm{Si}$ phase have remained. From these results, it is evident that the T4 treatment at $430{ }^{\circ} \mathrm{C}$ can dissolve most of $\mathrm{Al}_{3} \mathrm{Mg}_{2}$ phase but has a minimal impact on the Mn-rich intermetallic and $\mathrm{Mg}_{2} \mathrm{Si}$ phases. Figure 9 shows the appearance of the secondary phases and the corresponding EDS mapping of $\mathrm{Mg}$ element of $\mathrm{Al}-5.0 \mathrm{Mg}-0.6 \mathrm{Mn}-0.25 \mathrm{Ce}$ alloys under the as-cast and T4-treated conditions. Mg segregation occurs around the secondary phases in the as-cast condition, as shown in Fig. 9b. After T4 heat treatment, the Mg segregation disappears, as shown in Fig. 9d. It can be seen that $\mathrm{Mg}$ distribution in the T4-treated alloys is much more homogeneous than that of the as-cast alloys, while there are minimal changes in other secondary phases (such as the $\mathrm{Mg}_{2} \mathrm{Si}$ or Mn-rich phases). This phenomenon confirms that the $\mathrm{Al}_{3} \mathrm{Mg}_{2}$ phase is dissolved into $\alpha(\mathrm{Al})$ matrix during the $\mathrm{T} 4$ heat treatment. Additionally, the SDAS and area fraction of
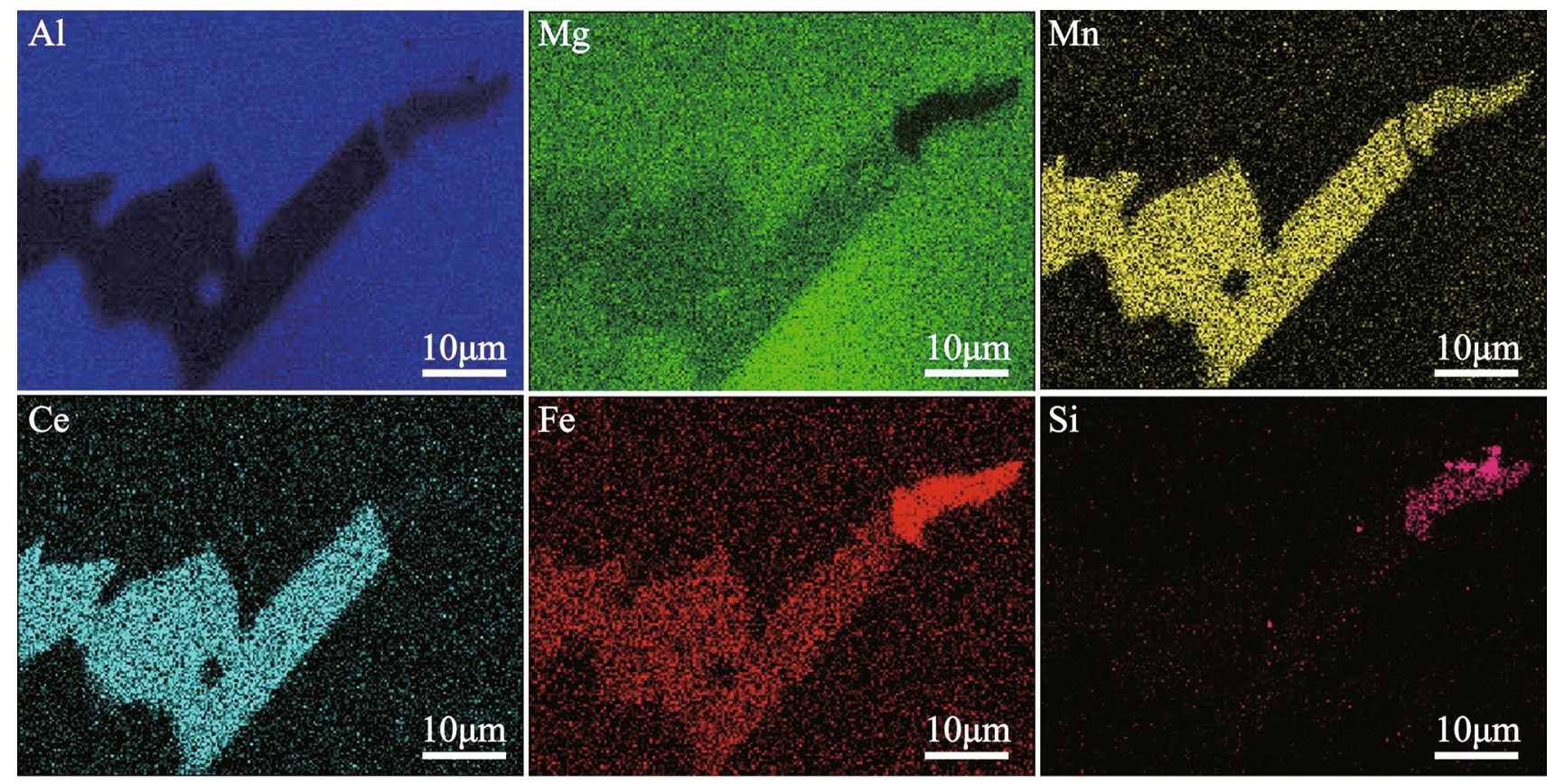

Fig. 7 Concentration mapping of $\mathrm{Al}, \mathrm{Mg}, \mathrm{Mn}, \mathrm{Ce}, \mathrm{Fe}$ and $\mathrm{Si}$ in Fig. 6a from the as-cast $\mathrm{Al}-5.0 \mathrm{Mg}-0.6 \mathrm{Mn}-0.25 \mathrm{Ce}$ alloy with a cooling rate of $0.22 \mathrm{~K} / \mathrm{s}$ 

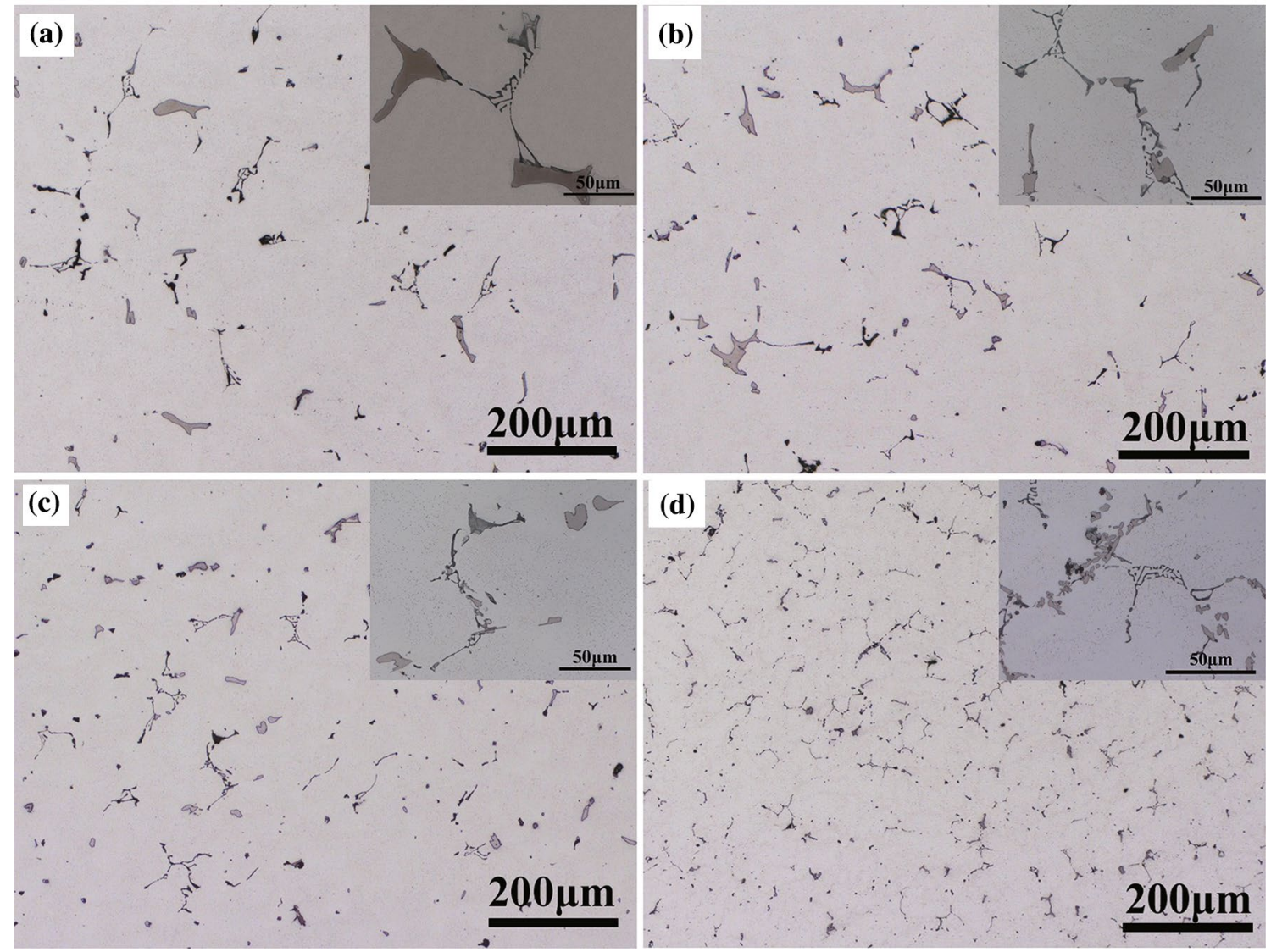

Fig. 8 Optical microstructures of the T4-treated Al-5.0Mg-0.6Mn-0.25Ce alloys produced at different cooling rates: a $0.22 \mathrm{~K} / \mathrm{s}$; b $0.33 \mathrm{~K} / \mathrm{s} ; \mathbf{c}$ $1.39 \mathrm{~K} / \mathrm{s} ; \mathbf{d} 7.65 \mathrm{~K} / \mathrm{s}$

Mn-rich phase were measured and are given in Table 5. As shown in this table and Table 3, the SDAS and area fraction of Mn-rich phase do not have many differences between the T4-heat-treated and the as-cast samples.

Figure 10 shows the typical TEM images for the T4-treated alloys fabricated at a cooling rate of $7.65 \mathrm{~K} / \mathrm{s}$. From Fig. 10a, some rodlike and block precipitates appear in Al matrix. The block particles ranged from 200 to $400 \mathrm{~nm}$ in size, while the apparent length and width of the rodlike particles varied from 300 to $500 \mathrm{~nm}$ and 80 to $120 \mathrm{~nm}$, respectively. Given that the composition of this alloy is $\mathrm{Al}-5.0 \mathrm{Mg}-0.6 \mathrm{Mn}-0.25 \mathrm{Ce}$, only several precipitates, including $\mathrm{Al}_{6} \mathrm{Mn}, \mathrm{Al}_{6}(\mathrm{Mn}, \mathrm{Fe})$ and $\mathrm{Al}_{3} \mathrm{Mg}_{2}$, can form during solidification and heat treatment process [23]. According to the morphological characteristics of precipitates in Fig. 10a, these precipitates are more likely to be Mn-rich phases. The corresponding selected area diffraction (SAED) analysis on the block particle shows that it corresponds to the [111] zone axis of $\mathrm{Al}_{6} \mathrm{Mn}$ phase, which is consistent with the results reported by Yan et al. [23]. However, the EDS measurement shows that the block particle consists of $\mathrm{Mn}$ - and Fe-rich elements with an average composition analogous to the $\mathrm{Al}_{6}(\mathrm{Mn}, \mathrm{Fe})$ phase (Fig. 10c). Thus, according to the EDS measurement, this block dispersoid is $\mathrm{Al}_{6}(\mathrm{Mn}, \mathrm{Fe})$ phase, rather than $\mathrm{Al}_{6} \mathrm{Mn}$ phase. This may be due to the crystal structure of $\mathrm{Al}_{6} \mathrm{Mn}$ and $\mathrm{Al}_{6}(\mathrm{Mn}, \mathrm{Fe})$ phase. It has been reported that both $\mathrm{Al}_{6} \mathrm{Mn}$ and $\mathrm{Al}_{6}(\mathrm{Mn}, \mathrm{Fe})$ phases have an orthorhombic crystal structure with small differences in lattice parameters $\left(a=6.4978, b=7.5518\right.$ and $c=8.8703 \AA$ for $\mathrm{Al}_{6} \mathrm{Mn}$, while $a=7.498, b=6.495$ and $c=8.8837 \AA$ for $\left.\mathrm{Al}_{6}(\mathrm{Mn}, \mathrm{Fe})\right)[24$, 25]. In fact, both $\mathrm{Al}_{6} \mathrm{Mn}$ and $\mathrm{Al}_{6}(\mathrm{Mn}, \mathrm{Fe})$ precipitates can form in $\mathrm{Al}-\mathrm{Mg}-\mathrm{Mn}(-\mathrm{Fe})$ alloys [17]. These Mn-rich dispersoids will benefit to the formation of $\beta-\mathrm{Al}_{3} \mathrm{Mg}_{2}$ during sensitization at low temperature from 50 to $70{ }^{\circ} \mathrm{C}$ for several months [26]. However, few $\beta-\mathrm{Al}_{3} \mathrm{Mg}_{2}$ phases are found around these $\mathrm{Mn}$-rich particles. Occasionally, several large precipitates ranging from 0.8 to $2.0 \mu \mathrm{m}$ are found at the grain boundaries, as shown in Fig. 10b. The morphology and size of the precipitates are obviously different from those in Fig. 10a. The corresponding EDS measurement (as shown in Fig. 10d) indicates the precipitate is likely to be $\beta-\mathrm{Al}_{3} \mathrm{Mg}_{2}$ phase. It is known that the grain boundaries can act as diffusion channels for $\mathrm{Mg}$ atoms, leading to the 

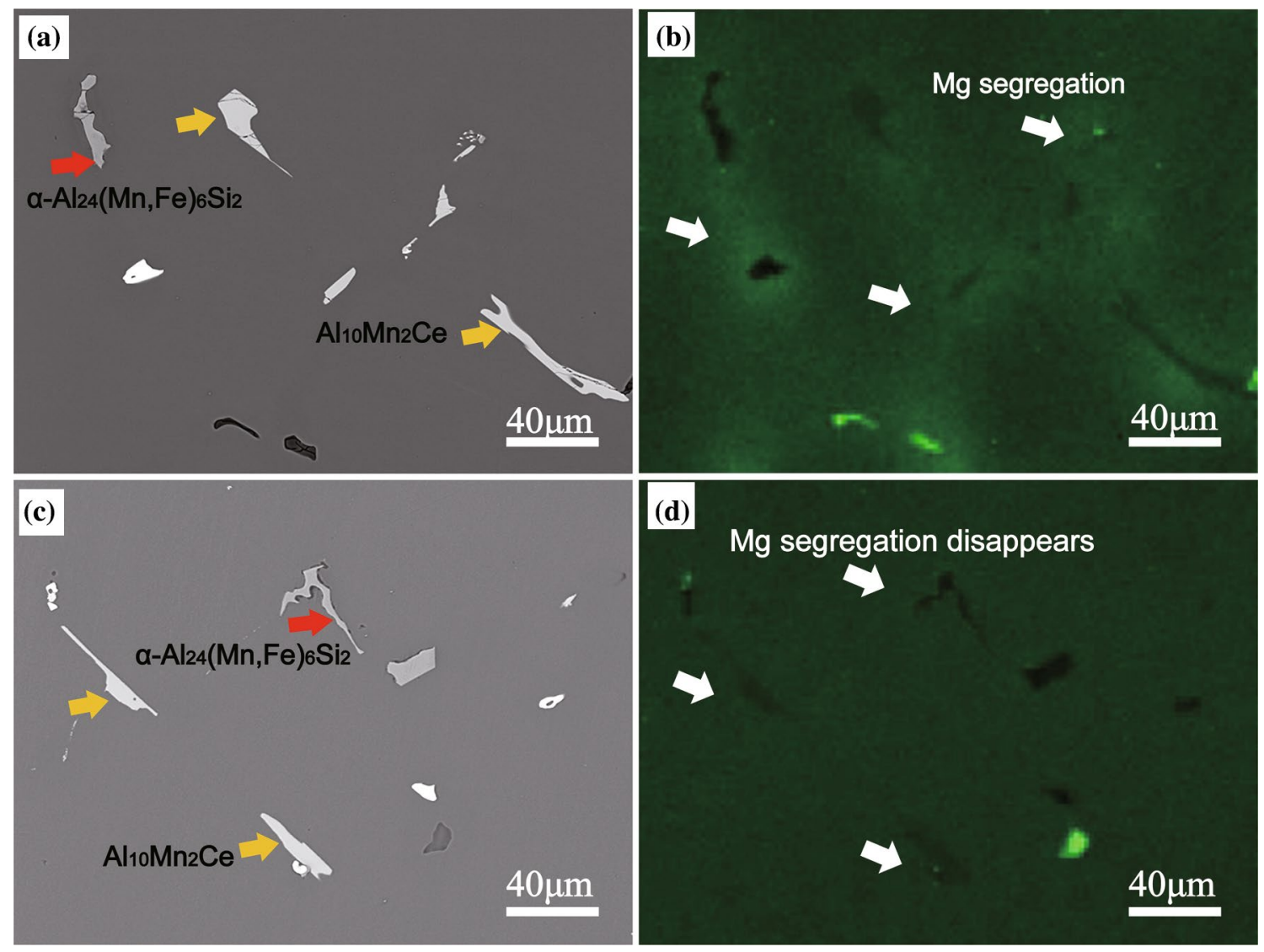

Fig. 9 SEM micrographs and the corresponding EDS mapping of $\mathrm{Mg}$ element of $\mathrm{Al}-5.0 \mathrm{Mg}-0.6 \mathrm{Mn}-0.25 \mathrm{Ce}$ alloys fabricated at a cooling rate of $0.22 \mathrm{~K} / \mathrm{s}$ under different states: $\mathbf{a}, \mathbf{b}$ as-cast; $\mathbf{c}, \mathbf{d}$ T4-treated

Table 5 SDAS of $\alpha(\mathrm{Al})$ dendrites, area fraction (\%) of $\mathrm{Al}_{3} \mathrm{Mg}_{2}$ and Mn-rich phase in the T4-treated Al-5.0 Mg-0.6Mn-0.25Ce alloys produced at different cooling rates

\begin{tabular}{lccll}
\hline $\begin{array}{l}\text { Thick- } \\
\text { ness } \\
(\mathrm{mm})\end{array}$ & $R_{\mathrm{c}}(\mathrm{K} / \mathrm{s})$ & SDAS $(\mu \mathrm{m})$ & \multicolumn{2}{l}{ Area fraction $(\%)$} \\
\cline { 4 - 5 } & & $\alpha(\mathrm{Al})$ dendrites & $\mathrm{Al}_{3} \mathrm{Mg}_{2}$ phase & Mn-rich phase \\
\hline 50 & 0.22 & $100.8 \pm 15.2$ & $\sim 0$ & $1.43 \pm 0.16$ \\
25 & 0.33 & $79.7 \pm 12.4$ & $\sim 0$ & $1.38 \pm 0.13$ \\
10 & 1.39 & $50.8 \pm 9.4$ & $\sim 0$ & $0.72 \pm 0.10$ \\
5 & 7.65 & $31.3 \pm 5.7$ & $\sim 0$ & $0.63 \pm 0.08$ \\
\hline
\end{tabular}

formation of $\mathrm{Al}_{3} \mathrm{Mg}_{2}$ phase. From the TEM observation, it is clear that there are some dispersoids in $\mathrm{Al}$ matrix or at the grain boundaries, including $\mathrm{Al}_{6}(\mathrm{Mn}, \mathrm{Fe})$ and $\mathrm{Al}_{3} \mathrm{Mg}_{2}$ dispersoids. However, due to the large size and a small amount of them, the dispersion strengthening in this alloy is relatively limited.

\subsection{Mechanical Properties}

Figure 11 shows the Vickers hardness test results at various cooling rates under both the as-cast and T4-treated conditions. As the cooling rate increases from 0.22 to $7.65 \mathrm{~K} / \mathrm{s}$, the hardness value increases slightly from 77.4 to $81.2 \mathrm{HV}$. The Vickers hardness values after T4 treatment are a little higher when compared with those of the as-cast alloys.

Tensile properties of the as-cast $\mathrm{Al}-5.0 \mathrm{Mg}-0.6 \mathrm{Mn}-0.25 \mathrm{Ce}$ alloys at different cooling rates are shown in Fig. 12. It is found that as the cooling rate increased from 0.22 to $7.65 \mathrm{~K} / \mathrm{s}$, the yield strength (YS) increased slightly from 98.1 to $112.8 \mathrm{MPa}$, the ultimate tensile strength (UTS) increased from 146.3 to $241.0 \mathrm{MPa}$, and the elongation (EL) increased from 4.4 to $12.2 \%$. A regression analysis showed that both UTS and EL are functions of the SDAS, as shown in Fig. 13, and can be represented by the following equations:

$\mathrm{UTS}=69.4+907.2\left(1 / \lambda_{2}\right)^{0.5}$,

$\mathrm{EL}=-2.1+78.6\left(1 / \lambda_{2}\right)^{0.5}$,

where $\lambda_{2}$ represents the SDAS (in $\mu \mathrm{m}$ ), while UTS and EL represent ultimate tensile strength (MPa) and elongation (\%), respectively. It can be seen that the UTS and EL significantly increase with the decrease in $\lambda_{2}$ and they are proportional to $\left(1 / \lambda_{2}\right)^{0.5}$. As discussed earlier, an increase in the cooling rate 

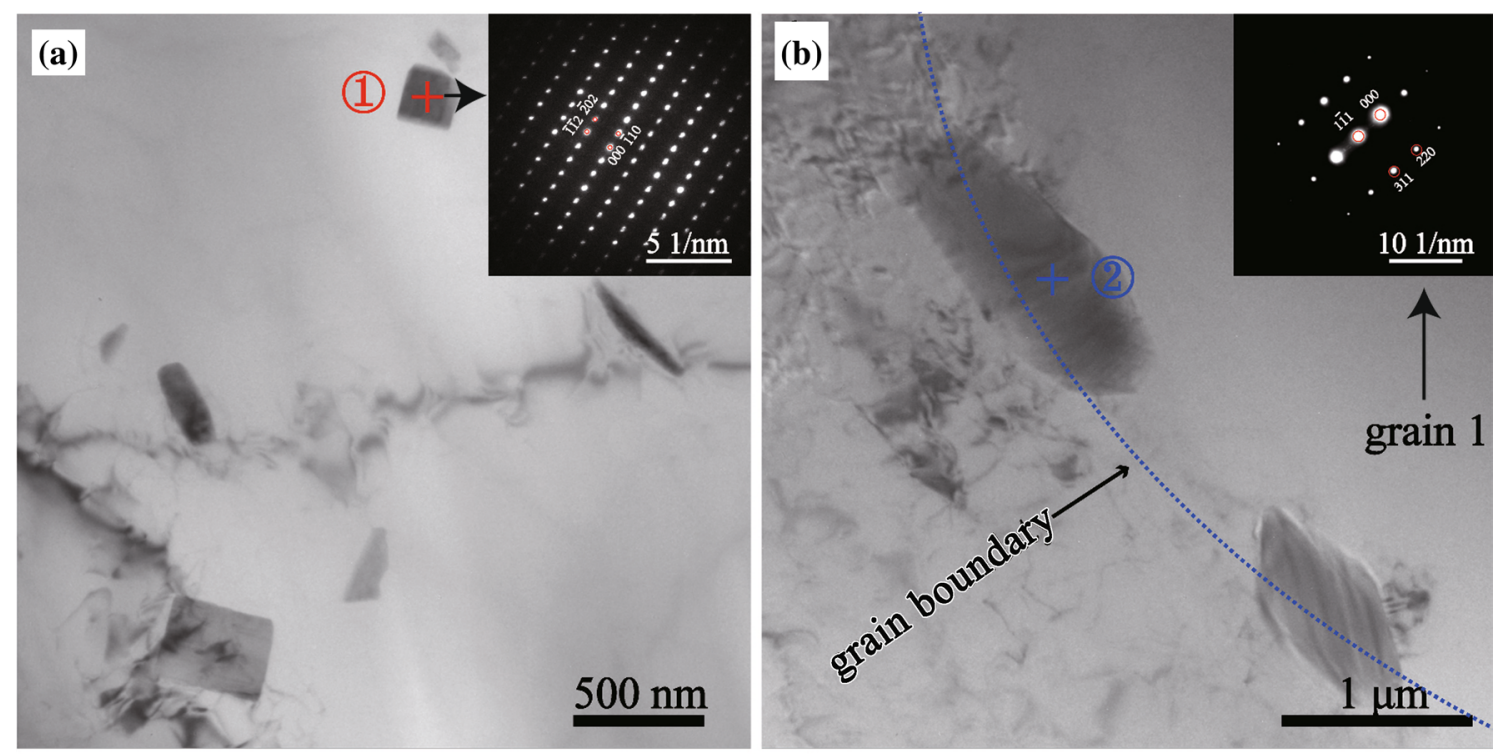

(c)

(d)
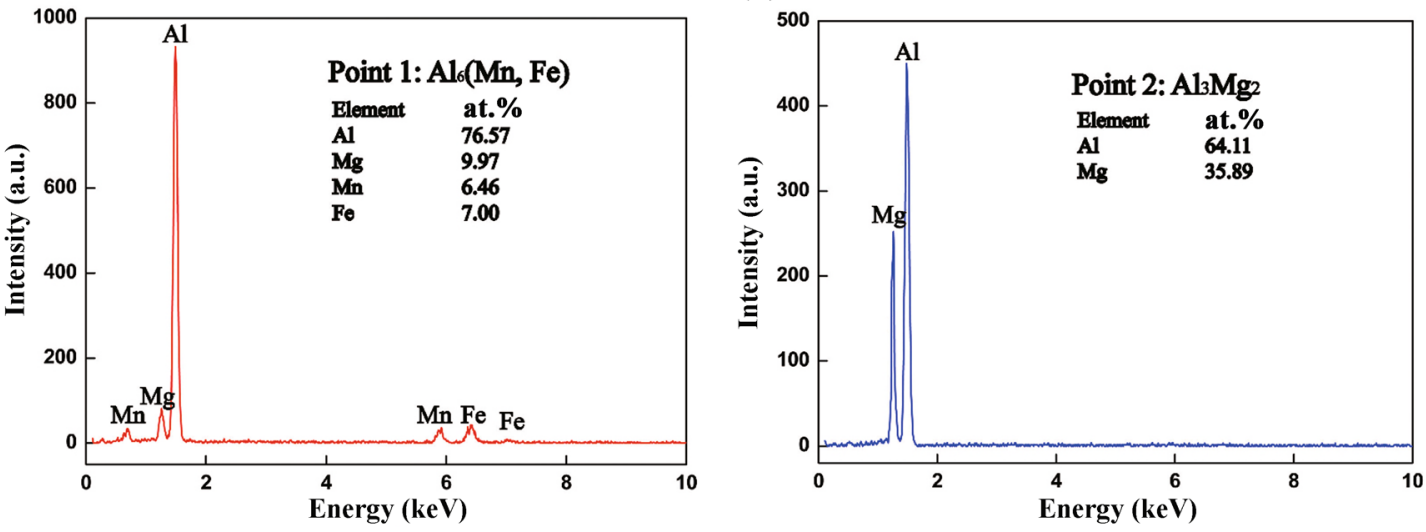

Fig. 10 TEM images for the T4-treated alloys fabricated at a cooling rate of $7.65 \mathrm{~K} / \mathrm{s}$; $\mathbf{a}$, b TEM bright-field images showing dispersoids in matrix and at grain boundary (the insets in $\mathbf{a}$ and $\mathbf{b}$ show the SAED patterns from the dispersoid and Al matrix, respectively; $\mathbf{c}, \mathbf{d}$ the EDS results of dispersoids in matrix and at grain boundary)

correlates with the refinement of the SDAS and secondary phases (Figs. 4, 7), causing an increase in elongation for the as-cast $\mathrm{Al}-5.0 \mathrm{Mg}-0.6 \mathrm{Mn}-0.25 \mathrm{Ce}$ alloys. As a result, higher UTS is obtained through the microstructure refinements and the strain hardening effect due to better ductility. Considering the relationship between $R_{\mathrm{c}}$ and $\lambda_{2}$ in Eq. (2), it is evident that increasing the cooling rate reduces the $\lambda_{2}$ and thus improves the UTS and EL based on Eqs. (3) and (4).

Figure 14 shows the mechanical properties of the T4-treated $\mathrm{Al}-5.0 \mathrm{Mg}-0.6 \mathrm{Mn}-0.25 \mathrm{Ce}$ alloys. After T4 heat treatment, both the strength (YS and UTS) and elongation are improved. The increment percentages of the change in strength and elongation before and after T4 heat treatment are shown in Fig. 15. It is obviously found that the increment percentage of YS, UTS and EL varies with the cooling rate. At a cooling rate of $0.22 \mathrm{~K} / \mathrm{s}$, the increment percentage of YS, UTS and EL reaches $12.4 \%, 47.0 \%$ and $65.9 \%$, respectively, while at a cooling rate of $7.65 \mathrm{~K} / \mathrm{s}$, these values reach lower values of $4.4 \%, 7.8 \%$ and $32.7 \%$, respectively. The increment percentages of strength and EL under low cooling rate condition are much larger than that under high cooling rate condition. Based on the above analysis, the T4 heat treatment improves mechanical properties of the ascast $\mathrm{Al}-5.0 \mathrm{Mg}-0.6 \mathrm{Mn}-0.25 \mathrm{Ce}$ alloy and that the cooling rate has a significant effect on the increment of strength and EL. This phenomenon is likely due to the eutectic $\mathrm{Al}_{3} \mathrm{Mg}_{2}$ phases being more dissolved into the $\alpha(\mathrm{Al})$ matrix during the T4 treatment. Furthermore, a higher cooling rate will result in the production of less of the $\mathrm{Al}_{3} \mathrm{Mg}_{2}$ phase in the as-cast microstructure (as shown in Fig. 4), thus improving the YS, UTS and EL. 


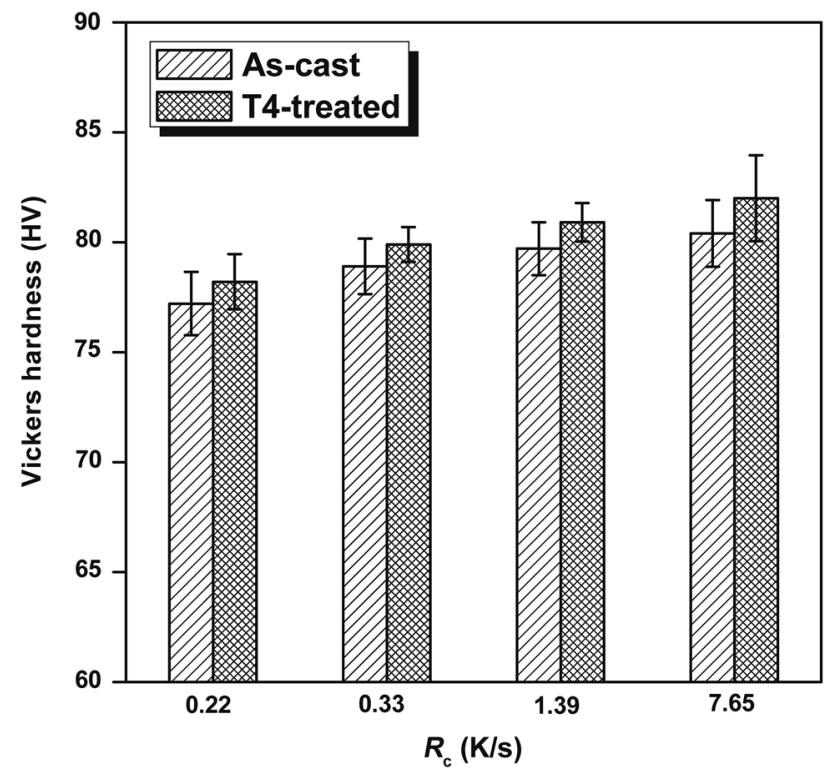

Fig. 11 Vickers hardness versus the cooling rate for studied alloys under as-cast and T4-treated conditions

\subsection{Fractography}

Figure 16 shows the fracture surfaces of the tensile specimens from the as-cast $\mathrm{Al}-5.0 \mathrm{Mg}-0.6 \mathrm{Mn}-0.25 \mathrm{Ce}$ alloys and the EDS results of the particles on the fracture surfaces. For the specimens under lower cooling rates, such as 0.22 and $0.33 \mathrm{~K} / \mathrm{s}$, a mixed fracture surface is observed. In these specimens, a fracture surface containing many cleavage planes, some fine broken phases (marked with red frame in Fig. 16) and minor dimples can be observed. According to the EDS results, these phases formed on the cleavage planes and fine broken phases are Mn-rich phases and $\mathrm{Al}_{3} \mathrm{Mg}_{2}$ phases, respectively. It seems that these phases tend to break first during tensile tests and lead to the initiation of microcracks. Therefore, alloys treated at lower cooling rates will tend to exhibit characteristics similar to brittle fractures. As the cooling rate increases to 1.39 and $7.65 \mathrm{~K} / \mathrm{s}$, the fracture surface shows more and more dimples, indicating that the alloy has become more ductile. This finding agrees with the results of tensile tests depicted in Fig. 12. The improvement in ductility is attributed to the refinement of $\alpha(\mathrm{Al})$ dendritic and homogeneous distribution of finer secondary phases caused by higher cooling rates.

Above observation on the fracture surfaces indicates that the cooling rate affects ductility significantly of the as-cast alloys, and these $\mathrm{Mn}$-rich phases and $\mathrm{Al}_{3} \mathrm{Mg}_{2}$ phases play an important role during the fracture process. This can be explained well by the stress concentration. It is known that high local stress concentrations occur during the tensile process and that the bonding force between the atoms is damaged by this stress concentration. As a result, some voids may begin to form in the $\mathrm{Al}$ matrix. With the continuous tensile process, three-dimensional stress concentrations form on micro-holes and the growth and coalescence of these voids create fracture sources. For the alloys analyzed, there are many brittle secondary phases where stress concentrations can form around, leading to the formation of micro-cracks and, in turn, poor ductility. On contrary, the refinement of $\alpha(\mathrm{Al})$ dendritic and the homogeneous distribution of secondary phases reduces the formation of these stress concentrations, improving the ductility of the as-cast alloys.

Figure 17 shows the fracture surfaces of the T4-treated specimens and the EDS results of the particles on the fracture surfaces. From this figure, it can be seen that many dimples and some cleavage planes are present on the fracture surfaces for all specimens. Also, the compositions of the cleavage plane obtained by EDS measurements are shown in Fig. 17e. These phases consist of Mn-, Fe- and Ce-rich
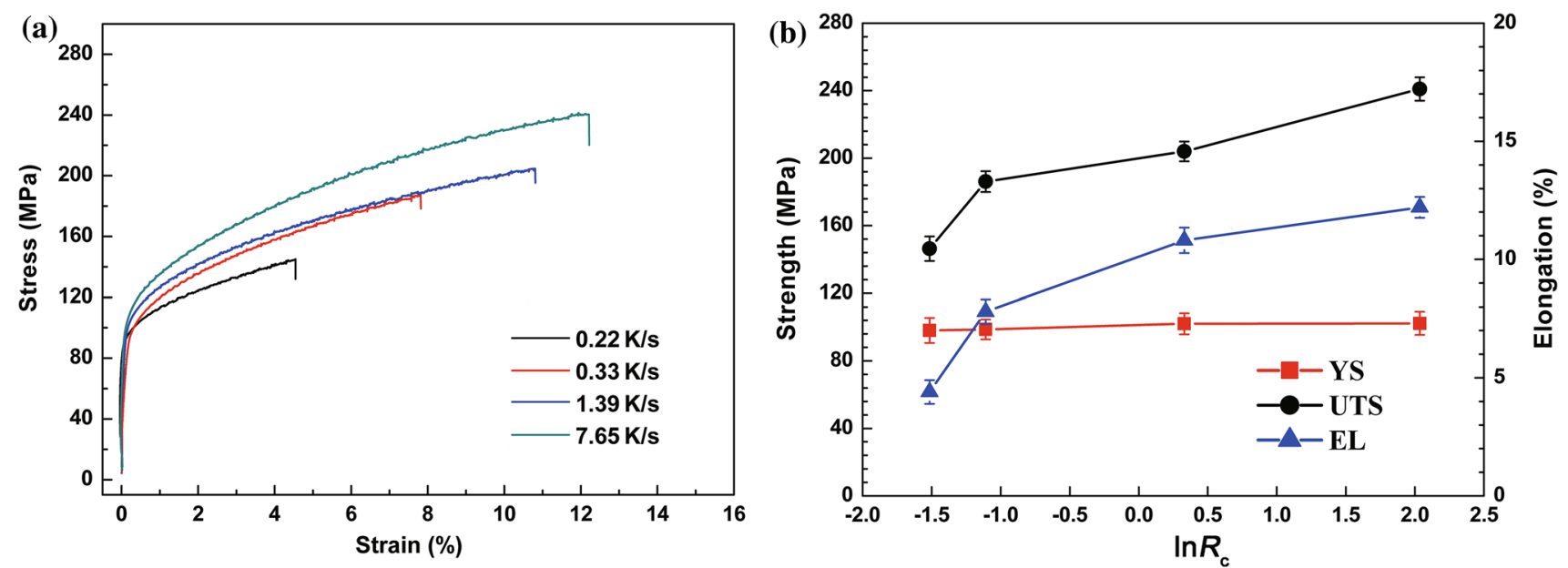

Fig. 12 a Typical tensile curves and $\mathbf{b}$ tensile properties of the as-cast $\mathrm{Al}-5.0 \mathrm{Mg}-0.6 \mathrm{Mn}-0.25 \mathrm{Ce}$ alloys produced under different cooling rates 

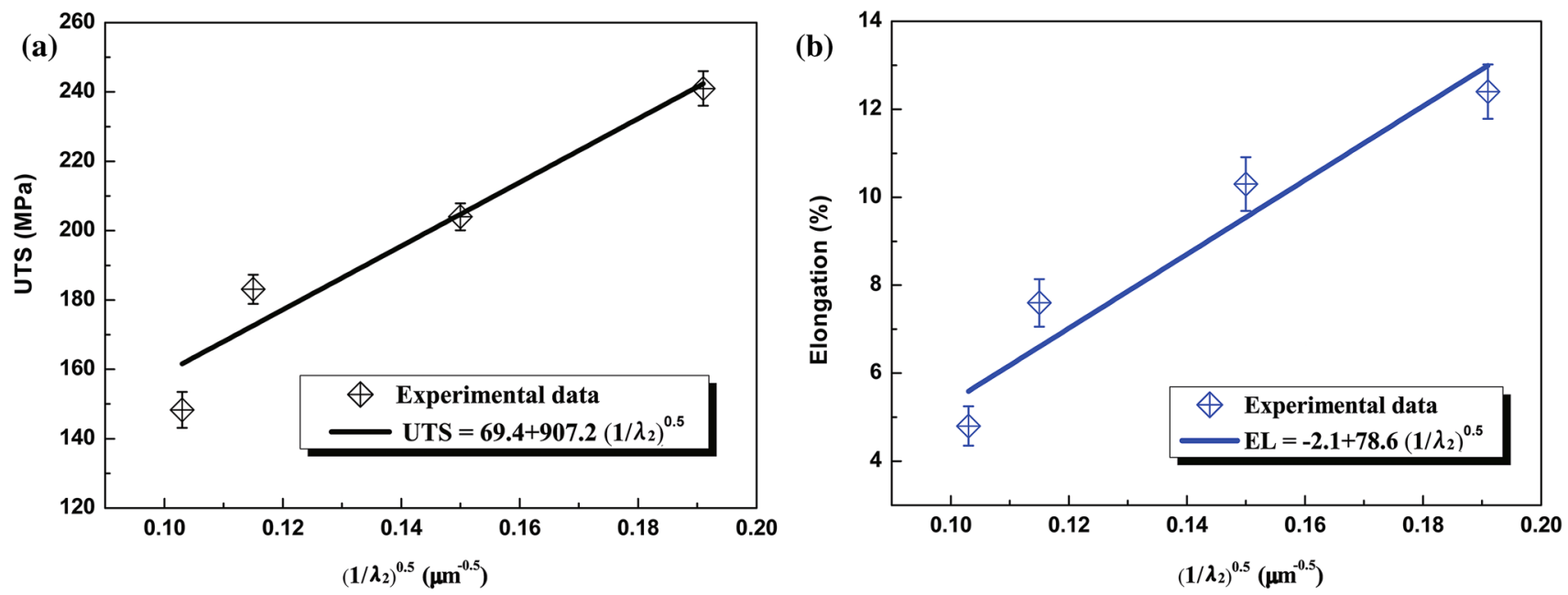

Fig. 13 Relationship between SDAS and a UTS, b EL for as-cast Al-5.0Mg-0.6Mn- $0.25 \mathrm{Ce}$ alloys
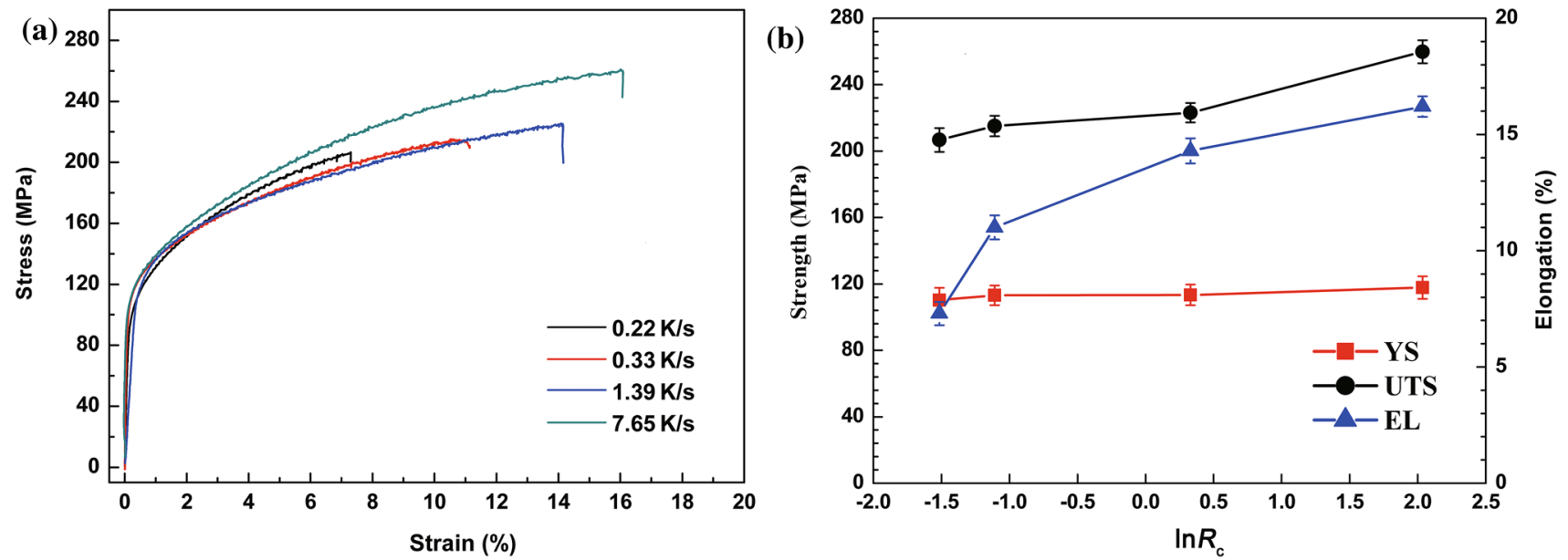

Fig. 14 a Typical tensile curves, $\mathbf{b}$ tensile properties of the T4-treated $\mathrm{Al}-5.0 \mathrm{Mg}-0.6 \mathrm{Mn}-0.25 \mathrm{Ce}$ alloys under different cooling rates

elements, with similar compositions shown in Fig. 16. With the increase in the cooling rate, more dimples appear on the fracture surface, indicating a positive correlation between higher cooling rates and ductility. When compared with the as-cast specimens, no fine broken phases are observed in the T4-treated samples. These fine broken phases depicted in the as-cast specimens disappear after T4 heat treatment, which implies that this granular phase is the broken eutectic $\mathrm{Al}_{3} \mathrm{Mg}_{2}$ phase. The dissolution of the brittle $\mathrm{Al}_{3} \mathrm{Mg}_{2}$ phase not only reduces the amount of secondary phases, but also provides an increased number of sites of fine dimples, therefore improving the ductility significantly.

\section{Discussion}

\subsection{Effect of Cooling Rate on Microstructural Evolution}

From the examination of the as-cast microstructure of Al-5.0Mg- $0.6 \mathrm{Mn}-0.25 \mathrm{Ce}$ alloys under different cooling rates, it can be deduced that the cooling rate plays a key role in the refinement of $\alpha$ - $\mathrm{Al}$ and intermetallic compounds. When the cooling rate increases from 0.22 to $7.65 \mathrm{~K} / \mathrm{s}$, both SDAS and the amount of eutectic $\mathrm{Al}_{3} \mathrm{Mg}_{2}$ are significantly reduced.

During solidification, $\alpha$-Al tends to exhibit dendritic growth, and statistical results show that the relationship between SDAS $\left(\lambda_{2}\right)$ and cooling rate $\left(R_{\mathrm{c}}\right)$ can be described 


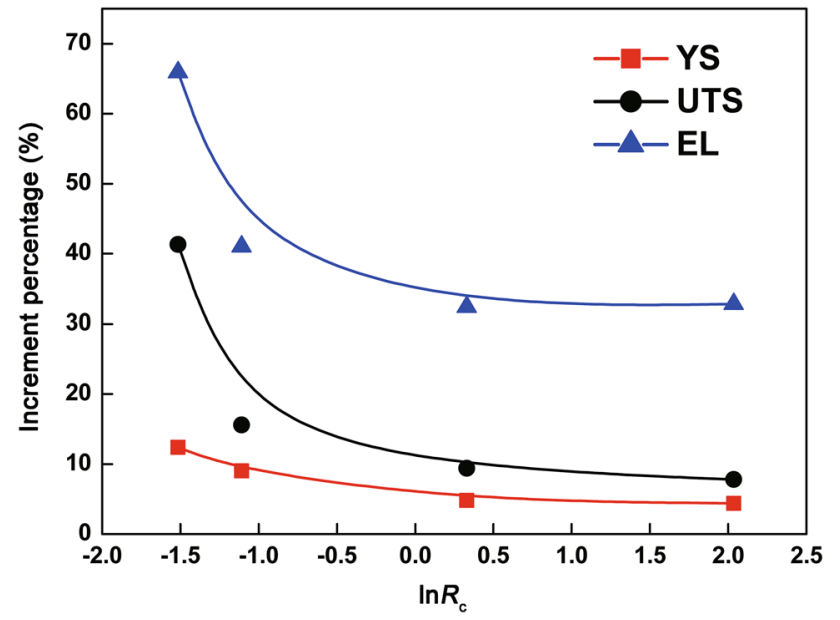

Fig. 15 Effect of the cooling rate on increment percentage of strength (YS and UTS) and elongation of alloys before and after T4 heat treatment, noting that the 'increment percentage' refers to the enhancement of properties compared to those of as-cast materials

well by an exponential equation, as shown in Eq. (2). This relation between them can be explained by the growth of secondary dendritic arms of multicomponent proposed by Rappaz et al. [27] and is given by:

$\lambda_{2}=5.5\left(M t_{\mathrm{SL}}\right)^{1 / 3}$,

where $t_{\mathrm{SL}}$ is the local solidification time and $M$ is dependent on the Gibbs-Thomson coefficient $(\Gamma)$, the liquidus slope $\left(m_{\mathrm{L}}\right)$, the final liquid composition $\left(c_{\mathrm{f}}\right)$ at the dendrite root, and the final solid composition $\left(c_{0}\right)$. The solidification time, $t_{\mathrm{SL}}$, is converted into a cooling rate using the relationship [27]:

$t_{\mathrm{SL}}=\Delta T / R_{\mathrm{c}}$,

where $\Delta T$ is the temperature interval between the liquidus and the eutectic onset, and $R_{\mathrm{c}}$ is the cooling rate. In the present work, $\Delta T$ is a constant, about $70 \mathrm{~K}$, as shown in Table 2 . Thus, the $\lambda_{2}$ can be expressed as

$\lambda_{2}=5.5(M \Delta T) /\left(3 R_{\mathrm{c}}^{-1 / 3}\right)$.

As described by the equation, the $-1 / 3$ theoretical exponent is nearly the same as the experimental exponent $(-0.345$, as shown in Fig. 5). With the increase in the cooling rate, the SDAS will be greatly reduced.

The final solidification zones are the regions with triangle grain boundaries and inter-dendrites, where the intermetallic compounds will be formed. The refinement of $\alpha$-Al grains results in the increase in these regions with triangle grain boundaries and inter-dendrites. Due to the increase in the number of these regions, the intermetallic compounds formed in the final solidification zones are extremely refined and distributed more even at higher cooling rate.
With the growth of primary $\alpha-\mathrm{Al}$, the solute $\mathrm{Mg}$ is enriched at the solid/liquid interface front during solidification. Once the composition of the remaining liquid in the final solidification zones has reached the eutectic composition, the eutectic reaction $\mathrm{L} \rightarrow \alpha-\mathrm{Al}+\mathrm{Al}_{3} \mathrm{Mg}_{2}$ occurs. However, with the increase in the cooling rate, the solidification process may transform to a non-equilibrium state and solute trapping will occur. In this case, the local non-equilibrium diffusion effect in bulk liquids plays an important role in solute redistribution at the interface. This leads to a diffusionless solidification with a complete solute trapping at a finite interface velocity, as demonstrated for binary alloy solidification [28, 29]. According to this solute trapping theory, more solute $\mathrm{Mg}$ will be dissolved in $\alpha$-Al with the increase in the cooling rate. This means that the remaining solute $\mathrm{Mg}$ in the final solidification zone is reduced and less of the $\mathrm{Al}_{3} \mathrm{Mg}_{2}$ phase is formed.

\subsection{Effect of Cooling Rate on Mechanical Properties}

The results of tensile tests show that both UTS and EL increase significantly with the decrease in $\lambda_{2}$ for the ascast $\mathrm{Al}-5.0 \mathrm{Mg}-0.6 \mathrm{Mn}-0.25 \mathrm{Ce}$ alloy and the relationships between them can be expressed by experimental formulas:

$\mathrm{UTS}=69.4+907.2\left(1 / \lambda_{2}\right)^{0.5}$

$\mathrm{EL}=-2.1+78.6\left(1 / \lambda_{2}\right)^{0.5}$.

Interestingly, similar formulas describing the relationships between the UTS, EL and $\lambda_{2}$ had also been reported in the cast $\mathrm{Al}-9.0 \mathrm{Si}$ [30] and $\mathrm{Al}-4.5 \mathrm{Cu}$ alloy [31]. However, these relationships have not been clearly examined and a corresponding model for these relationships has not been developed.

The strength of the as-cast alloys changes with the variation in secondary dendritic arm spacing (SDAS, $\lambda_{2}$ ), solute concentration, as well as phase components and their fractions (Tables 2, 3, 4), which are all influenced by the cooling rate. In order to understand empirical formulas related to these alloys, the following relationships among the cooling rate, microstructure characteristics and strengthening mechanisms should be considered. Firstly, strengthening mechanisms are related to the grain boundary strengthening, solute solution strengthening and strain hardening for the as-cast $\mathrm{Al}-5.0 \mathrm{Mg}-0.6 \mathrm{Mn}-0.25 \mathrm{Ce}$ alloy. As the cooling rate increases during solidification, the $\lambda_{2}$ begins to decrease, leading to finer $\alpha$-Al grains and an improvement in UTS due to grain boundary strengthening. Secondly, as discussed in Sect. 4.1, the solute $\mathrm{Mg}$ concentration in $\alpha$ Al matrix increases with the decrease in $\lambda_{2}$. This helps to enhance the UTS by solute solution strengthening. Moreover, secondary phases, such as Mn-rich phase and $\mathrm{Al}_{3} \mathrm{Mg}_{2}$, show finer size and better distribution with the refinement of 

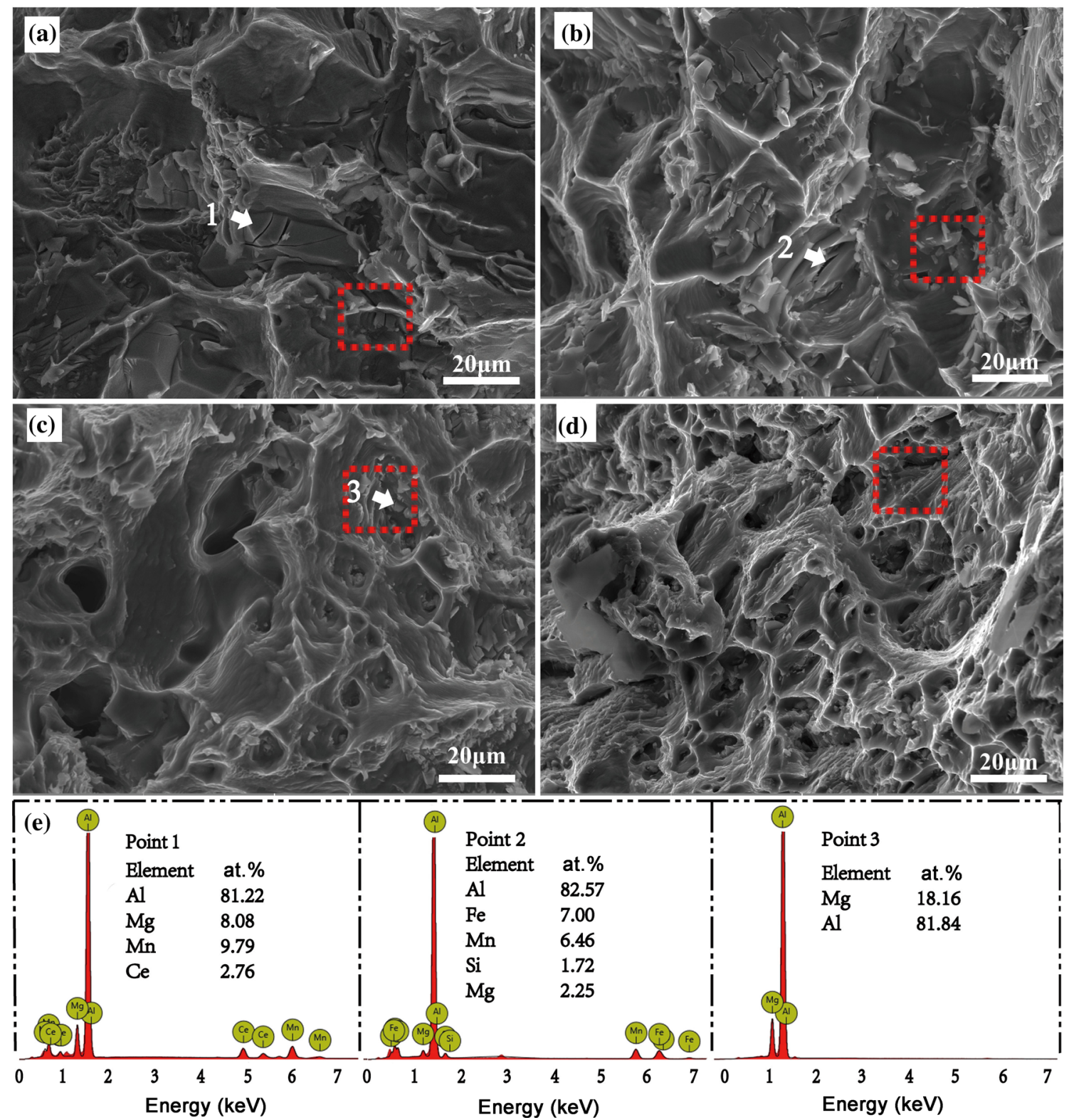

Fig. $16 \mathrm{SEM}$ micrographs of fractured tensile specimens from the as-cast $\mathrm{Al}-5.0 \mathrm{Mg}-0.6 \mathrm{Mn}-0.25 \mathrm{Ce}$ alloys at different cooling rates: a $0.22 \mathrm{~K} / \mathrm{s}$; b $0.33 \mathrm{~K} / \mathrm{s} ; \mathbf{c} 1.39 \mathrm{~K} / \mathrm{s} ; \mathbf{d} 7.65 \mathrm{~K} / \mathrm{s}$; e EDS results of particles on fracture surfaces

$\lambda_{2}$, leading to higher ductility. As a result, an enhancement of strain hardening is obtained. In summary, these strengthening mechanisms related to UTS are directly or indirectly influenced by the $\lambda_{2}$, which in turn is directly controlled by the cooling rate. Thus, it seems reasonable that the UTS can be expressed by Eq. (8).

It should be noted that although there is a clear relationship among cooling rate, microstructure and strength (as discussed above), it is difficult to distinguish how the cooling rate contributes (whether through an interplay between SDAS, solute concentration, phase components and their fractions) to UTS using the relationship between SDAS and
UTS. In fact, it is difficult to calculate the contribution to strength accurately by experimental research due to complexities of the as-cast microstructures. To more accurately examine this relationship, simulation calculation studies would likely be much more effective. A dislocation plug model [32] could likely also be used to analyze this relationship. Although the experimental equations using $R_{\mathrm{c}}, \lambda_{2}$, UTS and EL are not perfectly accurate, these mathematical models are useful tools that can be used to manipulate the relation of cooling rate with the tensile properties of the ascast $\mathrm{Al}$ components. For example, Quarema et al. [31] used the experimental formulas in $\mathrm{Al}-4.5 \mathrm{Cu}$ cast alloy to predict 

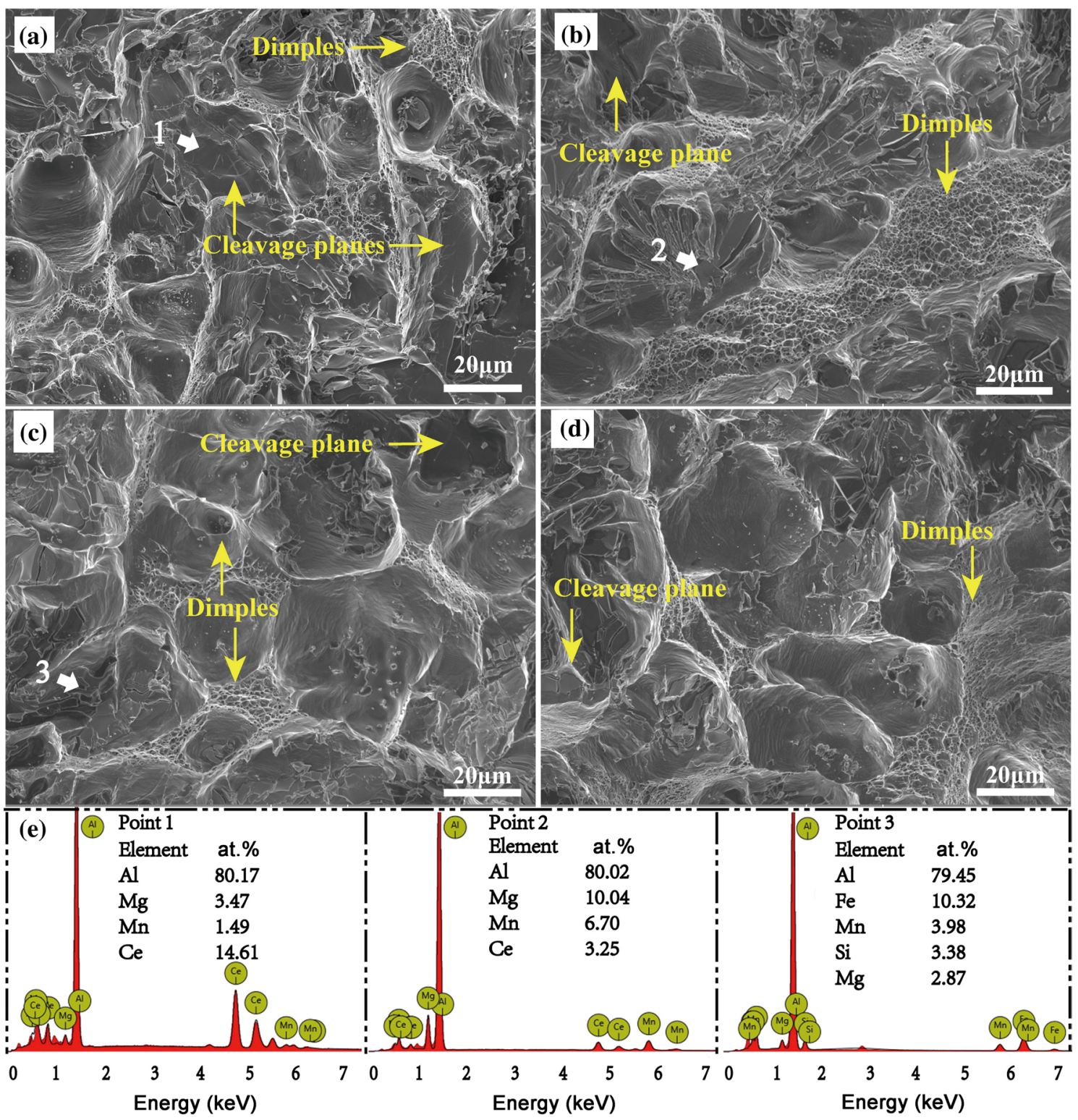

Fig. 17 SEM micrographs of fractured tensile specimens from the T4-treated $\mathrm{Al}-5.0 \mathrm{Mg}-0.6 \mathrm{Mn}-0.25 \mathrm{Ce}$ alloys at different cooling rates: a $0.22 \mathrm{~K} / \mathrm{s} ; \mathbf{b} 0.33 \mathrm{~K} / \mathrm{s} ; \mathbf{c} 1.39 \mathrm{~K} / \mathrm{s} ; \mathbf{d} 7.65 \mathrm{~K} / \mathrm{s}$; e EDS results of particles on fracture surfaces

the effect of foundry processes on the final mechanical properties of alloys with relatively accurate degree.

After the T4 heat treatment, both strength and elongation of T4-treated alloys increased when compared with the ascast alloys. For these as-cast alloys, eutectic $\mathrm{Al}_{3} \mathrm{Mg}_{2}$ phases are present at the grain boundaries. After the $\mathrm{T} 4$ heat treatment at $430{ }^{\circ} \mathrm{C}$ for $12 \mathrm{~h}$, most of eutectic $\mathrm{Al}_{3} \mathrm{Mg}_{2}$ phases were dissolved in the $\alpha$-Al matrix. As a result, the brittle phases were reduced, resulting in the reduction in stress concentrations. Additionally, the disappearance of $\mathrm{Al}_{3} \mathrm{Mg}_{2}$ phase will correlate with an increase in SDAS, indicating an increased dislocation slip distance. Because of both the reduction in brittle phases and an increase in SDAS [33], the elongation of the alloy can greatly increase. Moreover, the strength also increases due to an enhancement of the solid solution strengthening and strain hardening processes. The amount of eutectic $\mathrm{Al}_{3} \mathrm{Mg}_{2}$ phases is also influenced by the cooling rate. More eutectic $\mathrm{Al}_{3} \mathrm{Mg}_{2}$ phases are formed under low cooling rates condition, while less eutectic $\mathrm{Al}_{3} \mathrm{Mg}_{2}$ phases are formed under high cooling rates condition (Fig. 4). Thus, the incremental percentage of strength (YS and UTS) and elongation under different cooling rates is different, as shown in Fig. 14. Higher increments are obtained at low cooling rate $(0.22$ and $0.33 \mathrm{~K} / \mathrm{s})$, while lower increments are obtained at high cooling rate $(1.39$ and $7.65 \mathrm{~K} / \mathrm{s})$. 


\section{Conclusions}

(1) The effect of the cooling rate on the microstructure and mechanical properties of $\mathrm{Al}-5.0 \mathrm{Mg}-0.6 \mathrm{Mn}-0.25 \mathrm{Ce}$ alloy was investigated systematically at cooling rates between 0.22 and $7.65 \mathrm{~K} / \mathrm{s}$. By increasing the cooling rate from 0.22 to $7.65 \mathrm{~K} / \mathrm{s}$, the average SDAS is greatly reduced from 94.8 to $27.3 \mu \mathrm{m}$. The relationship between SDAS $\left(\lambda_{2}\right)$ and the cooling rate fits well with the following equation: $\lambda_{2}=53.0 R_{\mathrm{c}}^{-0.345}$. Additionally, increasing the cooling rate will not only refine the secondary phases, but also promote the transition from $\mathrm{Al}_{10} \mathrm{Mn}_{2} \mathrm{Ce}$ to $\alpha-\mathrm{Al}_{24}(\mathrm{Mn}, \mathrm{Fe})_{6} \mathrm{Si}_{2}$ phase.

(2) By increasing the cooling rate, the tensile properties of the as-cast alloys are significantly improved. As the cooling rate increases from 0.22 to $7.65 \mathrm{~K} / \mathrm{s}$, the UTS increases from 146.3 to $241.0 \mathrm{MPa}$ and the EL increases from 4.4 to $12.2 \%$. Experimental equations of the UTS and EL with $\operatorname{SDAS}\left(\lambda_{2}\right)$ have been proposed and can be represented by the formulas: UTS $=69.4+907.2\left(1 / \lambda_{2}\right)^{0.5}$ and $\mathrm{EL}=-2.1+78.6\left(1 / \lambda_{2}\right)^{0.5}$, respectively.

(3) The cooling rate affects the incremental percentage of both strength and elongation caused by T4 treatment. A higher increment is obtained at a lower cooling rate, while a lower increment is obtained under a higher cooling rate. This is related to the effect of the cooling rate on the amount of the $\mathrm{Al}_{3} \mathrm{Mg}_{2}$ phase. The $\mathrm{T} 4$ heat treatment dissolves most of the eutectic $\mathrm{Al}_{3} \mathrm{Mg}_{2}$ phase in the as-cast microstructure, further improving the YS, UTS and EL of the as-cast alloys.

(4) With increasing the cooling rate, the fracture mode transforms from mixed fracture to a more ductile fracture for the as-cast alloys, while the fracture mode is a ductile fracture for the T4-treated alloys.

Acknowledgements This work was supported financially by the National Natural Science Foundation of China (No. 51674166). Also, many thanks are given to Colin Luo for his editing work in English, who is from University of Calgary in Canada.

\section{References}

[1] R.A. Sielski, Ships Offshore Struct. 3, 57 (2008)

[2] S.W. Lee, J.W. Yeh, Mater. Sci. Eng. A 460, 409 (2007)
[3] Q. Wu, S.B. Kang, Acta Mater. Sin. (Engl. Lett.) 12, 521 (1999)

[4] S. Seifeddine, S. Johansson, I.L. Svensson, Mater. Sci. Eng. A 490, 385 (2008)

[5] T. Radetić, M. Popović, E. Romhanji, Mater. Charact. 65, 16 (2012)

[6] M. Król, T. Tański, P. Snopiński, B. Tomiczek, J. Therm. Anal. Calorim. 127, 299 (2017)

[7] Y.L. Liu, G.R. Huang, Y.M. Sun, L. Zhang, Z.W. Huang, J.J. Wang, C.Z. Liu, Materials 9, 88 (2016)

[8] J.D. Du, D.Y. Ding, W.L. Zhang, Z. Xu, Y.G. Gao, G.Z. Chen, X.H. You, R.Z. Chen, Y.W. Huang, J.S. Tang, Mater. Charact. 142, 252 (2018)

[9] S. Thompson, S.L. Cockcroft, M.A. Wells, Mater. Sci. Technol. 20, 497 (2004)

[10] P. Zhang, Z.M. Li, B.L. Liu, W.J. Ding, L.M. Peng, Mater. Sci. Eng. A 651, 376 (2016)

[11] Y.L. Liu, Y.M. Sun, L. Zhang, Y.H. Zhao, J.J. Wang, C.Z. Liu, Metals 7, 428 (2017)

[12] Y.L. Liu, L. Luo, C.F. Han, L.Y. Ou, J.J. Wang, C.Z. Liu, J. Mater Sci. Technol. 32, 305 (2016)

[13] J.R.P. Rodrigues, M.L.N.M. Melo, R.G.J. dos Santos, Mater. Sci. 45, $2285(2010)$

[14] L.F. Gomes, B.L. Silva, A. Garcia, J.E. Spinelli, Metall. Mater. Trans. A 48, 1841 (2017)

[15] I. Polmear, D. StJohn, J.F. Nie, M. Qian, Light Alloys, 5th edn. (Elsevier, Boston, 2017), pp. 109-156

[16] I.U. Haq, J.S. Shin, Z.H. Lee, Met. Mater. Int. 10, 89 (2004)

[17] F.G. Coury, E.L. Pires, W. Wolf, F.P. Almeida, A.L. Silva, W.J. Botta, C.S. Kiminami, M.J. Kaufman, J. Alloys Compd. 727, 460 (2017)

[18] G.S. Yi, B.H. Sun, J.D. Poplawsky, Y.K. Zhu, M.L. Free, J. Alloys Compd. 740, 461 (2018)

[19] R. Chen, Y.F. Shi, Q.Y. Xu, B.C. Liu, Trans. Nonferrous Met. Soc. China 24, 1645 (2014)

[20] Y.L. Liu, S.B. Kang, Mater. Sci. Technol. 13, 331 (1997)

[21] V.A. Hosseini, S.G. Shabestari, R. Gholizadeh, Mater. Des. 50, 7 (2013)

[22] S.X. Ji, W.C. Yang, F. Gao, D. Watson, Z.Y. Fan, Mater. Sci. Eng. A 564, 130 (2013)

[23] J. Yan, A.M. Hodge, J. Alloys Compd. 703, 242 (2017)

[24] A. Nicol, Acta Crystallogr. A 6, 285 (1953)

[25] L.D. Calvert, P. Villars, Pearson's Handbook of Crystallographic Data for Intermetallic Phases (ASTM International, Newbury, 1991)

[26] G. Yi, D.A. Cullen, K.C. Littrell, W. Golumbfskie, E. Sundberg, Metall. Mater. Trans. A 48, 2040 (2017)

[27] M. Rappaz, W.J. Boettinger, Acta Mater. 47, 3205 (1999)

[28] S.L. Sobolev, Acta Mater. 60, 2711 (2012)

[29] S.L. Sobolev, L.V. Poluyanov, F. Liu, J. Cryst. Growth 395, 46 (2014)

[30] W.R. Osorio, P.R. Goulart, A. Garcia, G.A. Santos, C.M. Neto, Metall. Mater. Trans. A 37, 2525 (2006)

[31] J.M. Quaresma, C.A. Santos, A. Garcia, Metall. Mater. Trans. A 31, 3167 (2000)

[32] V. Bata, E.V. Pereloma, Acta Mater. 52, 657 (2004)

[33] S.K. Shaha, F. Czerwinski, W. Kasprzak, J. Friedman, D.L. Chen, Mater. Sci. Eng. A 636, 361 (2015) 